\title{
Response of the aquatic invertebrate community to the eradication of an exotic invasive fish after 30 years of its introduction in an Iberian alpine lake.
}

Manuel Toro ${ }^{1}$ (ORCID: 0000-0002-4860-7229), Ignacio Granados² (ORCID: 0000-0002-8669-6613), Ángel Rubio ${ }^{2}$ (ORCID: 0000-0003-0078-8742), Antonio Camacho ${ }^{3}$ (ORCID: 0000-0003-0841-2010), Ibor Sabás $^{4}$ (ORCID: 0000-0002-4173-5332), Marc Ventura ${ }^{4}$ (ORCID: 0000-0003-1401-414X), Carlos Montes $^{5}$ (ORCID: 0000-0002-5233-0576)

${ }^{1}$ Centro de Estudios Hidrográficos (CEDEX). Paseo Bajo Virgen del Puerto, 3. E-28005 Madrid, Spain.

${ }^{2}$ Centro de Investigación, Seguimiento y Evaluación. Parque Nacional de la Sierra de Guadarrama. Cta. M-604, Km 28, E-28740 Rascafría, Madrid, Spain.

${ }^{3}$ Instituto Cavanilles de Biodiversidad y Biología Evolutiva (ICBiBE). Universitat de València. E-46980 Paterna, Valencia, Spain.

${ }^{4}$ Integrative Freshwater Ecology Group (IFE). Centre d'Estudis Avançats de Blanes (CEAB). Consell Superior d'Investigacions Científiques (CSIC). Accés Cala Sant Francesc, 14, 17300 Blanes, Girona, Catalonia, Spain.

${ }^{4}$ Departamento de Ecología. Universidad Autónoma de Madrid. Edificio de Biología, Facultad de Ciencias. Ciudad Universitaria de Cantoblanco. C/ Darwin, 2. E-28049 Madrid, Spain.

Corresponding author

E-mail: manuel.toro@cedex.es

Phone: +34913358001 .

\section{ABSTRACT}

In Lake Grande de Peñalara, an originally fishless small high mountain lake in the Central Iberian Peninsula, the brook trout was introduced in the $70 \mathrm{~s}$, eradicating 30 years later using gillnets. We investigated the time-course and changes in macroinvertebrates and zooplankton communities, before and after the eradication, by studying their richness and several biological and ecological traits of macroinvertebrates providing advantages or disadvantages against fish predation and colonising the different habitats. Macroinvertebrates richness increased from 13 taxa coexisting with fish, up to a maximum of 27 taxa after the eradication. Rare groups usually affected by fish predation, e.g. swimmers in surface and open waters, showed high dispersal and recolonization capabilities, while those with burrowing, interstitial or crawler habits maintained their presence even with fish given their advantage to hide from direct fish sight. Taxa with affinities for rare habitats within the lake (e.g. macrophyte beds) appeared occasionally 4-6 years after eradication. Contrastingly, zooplankton assemblage did not significantly change in richness in the next 10 years after eradication. No new species of cladocerans or copepods appeared after fish removal, but 4 new rotifers appeared and 5 taxa disappeared. This was apparently more related to a change in water quality or trophic status as a consequence of the fish removal than to the direct 
effect of fish removal on rotifers. In contrast, zooplankters were significantly smaller, on average, before fish eradication than later, indicating that the community responded to the change of predation pressure.

Keywords: high mountain lakes, traits, fish eradication, recovery, aquatic invertebrates, zooplankton

\section{INTRODUCTION}

Most high mountain lakes are naturally fishless because their remote locations in steep terrain, make it difficult for fishes to go upstream to reach them. If fish naturally colonized some of these lakes in the ancient past, they needed to be adapted to very harsh conditions such as scarce food resources in ultra- or oligotrophic waters, and very cold waters with winter ice-cover during several months, which furthermore could generate deep oxygen depletion in deeper layers. In naturally fishless high mountain lakes, the effects of introduction of allochthonous fish have been illustrated for many different regions of the world. Decreases in larger-sized zooplankton and benthic invertebrates after fish introductions were observed in North American lakes, specifically in California (Bradford et al. 1998; Knapp et al. 2001), Colorado (Lafrancois et al. 2003), Utah (Carlisle and Hawkins 1998) and Western Canada (Donald et al. 2001; Leavitt et al. 1994, Parker et al. 2001; Schindler et al. 2001), as well as in Northern Italy (Magnea et al. 2013; Tiberti et al. 2014), France (Cavalli et al. 2001), Austria (Schabetsberger et al. 2009), Portugal (Boavida and Gliwicz 1996), and Poland (Gliwicz 1980; Sienkiewicz and Gąsiorowski 2016) in Europe. Negative effects of fish introduction in lakes have also been recorded for amphibians (Braña et al. 1996), submerged macrophytes (Gacia et al. 2018) and natural fish assemblages (Miró and Ventura 2015) in Spain: these introductions also resulted in increases in the abundance of patogens and virulent bacteria in Northern Italian lakes (Pastorino et al. 2018). However, no significant differences were found for large zooplankton species densities or for the composition of the zooplankton assemblages in a few cases when comparing lakes with and without fish, as in Switzerland (Winder et al. 2001) and Bolivia (Aguilera et al. 2006). A similar lack of effects was also reported for benthic invertebrate assemblages in lakes from New Zealand (Wissinger et al. 2006). Benthic macroinvertebrates and zooplankton are the most affected by these fish introductions when they become the main food resource for the new guests (De Mendoza et al. 2012; Gliwicz and Rowan 1984, 1985; McNaught et al. 1999; Schindler and Parker 2002; Sienkiewicz and Gąsiorowski 2016; Tiberti et al. 2014), though also other indigenous fish can be affected or even become extinct (Nelson and Paetz 1992). The cascade effects on the whole lake ecosystem of fish introductions were evidenced in many cases, affecting trophic status (Sienkiewicz and Gąsiorowski 2016) by enhancing phosphorus recycling, making it available for algal production (Leavitt et al. 1994). In small lakes, large zooplankton species like Daphnia can frequently become extinct because of fish predation. As a result, smaller zooplankters like rotifers (eg. Keratella, Polyarthra) can increase their densities (Schindler and Parker 2002).

Long term (more than decades) effects of introduced fish in high mountain lakes, usually located in areas with strong barriers for dispersal of organisms (Donald et al. 2001), pose the question to what extent the recovery towards the ecosystem's original status is possible if the main pressure (introduced fish) is reduced 
or removed. Some aquatic invertebrates have adult phases that are able to fly relatively long distances and colonize new aquatic water bodies, but alpine environments display landscape barriers which difficult dispersal (Bitusik et al. 2017). Amphibians, if they have found refuge in small fishless ponds, can recolonize lakes once restored to a fishless condition if there are no physical barriers and long distances among them (Knapp et al. 2007; Tiberti et al. 2014). Some zooplankton species have resting stages which can maintain their viability for long periods in the sediments (Brendonck and De Meester 2003; Schindler and Parker 2002), though presumably, after some decades, this ability would be minimized by burying due to sedimentation processes. Moreover, the probability of colonization of water bodies located in remote areas is lower.

After the total elimination of fish in some high mountain lakes, the invertebrate assemblages showed different degrees of recovery or changes depending on aspects such as the lake morphometry, the existence and quality of refuge habitats (Carlisle and Hawkins 1998), and the presence of resting eggs in sediments (McNaught et al. 1999; Parker et al. 2001; Schindler and Parker 2002). A decade or even longer periods were needed in some lakes to approach the original or natural communities' state (Donald et al. 2001; Schindler and Parker 2002). Thus, the resilience of biological communities after the eradication of fish species introduced in the past in alpine lacustrine ecosystems can be influenced by multiple factors (Donald et al. 2001; Knapp et al. 2001; Knapp and Matthews 1998; Knapp and Sarnelle 2008; McNaught et al. 1999; Parker et al. 2001; Sarnelle and Knapp 2004; Tiberti 2017; Tiberti et al. 2018).

The functional structure of macroinvertebrate assemblages based on their species traits combinations can be used to detect differences among them and responses caused by fish predation, and therefore, to describe the stability of the community (resistance) (Usseglio-Polatera et al. 2000, 2001). Species traits are attributes describing preferences and adaptations to environmental conditions related to biological, physiological and ecological aspects, and can be characterized at the genus or even family taxonomic level to study and describe the diversity of macroinvertebrate communities (Tachet 2000; Usseglio-Polatera et al. 2000). The study of biological and ecological traits that can provide macroinvertebrates with advantages, or disadvantages, confronting fish predation, such as body size, locomotion, dispersal mechanisms, or life cycle duration, can be a useful tool in the evaluation of restoration measures in aquatic systems, as well as in the assessment of the recovery ability of this type of ecosystems when facing certain pressures. These can be used as indicators of the adaptation capabilities of different taxa when facing stress situations, also illustrating the process of restoration and transit towards a fishless scenario. Therefore, the study of functional diversity of biological communities, represented by functional traits of species, can help to the assessment of ecosystems disturbance, their processes and biodiversity (Villéger et al. 2010).

Most of Iberian high mountain lakes are naturally fishless, and only a few autochthonous fish species are present in some of them (Doadrio 2002). During the last century, in order to expand the possibilities of sport fishing in mountain areas, some non-native fish species were released for angling in many Iberian high mountain lakes. Most of them were salmonid species, well adapted to these cold environments: (Gacia et al. 2018; García-Berthou et al. 2015; Miró and Ventura 2015; Toro et al. 2006; Ventura et al. 2017). 
Brook trout (Salvelinus fontinalis) is native to NE United States where it lives in lakes, streams, estuaries, or even with anadromous habits (Scott and Scott, 1988). This species has been introduced in many high mountain lakes because it is well adapted to oligotrophic waters, surviving under the ice over long periods, and requires cold waters (optimum temperature range of 10 to $14^{\circ} \mathrm{C}$ ) and oxygen concentrations greater than $5 \mathrm{mg} / \mathrm{l}$ (Ficke et al. 2009; Scott and Scott, 1988). Adults feed mainly on insects or small fish, and only small emergent fry $(<3 \mathrm{~cm}$ ) feed on zooplankton or macroscopic crustaceans (Karas 1997; Tiberti et al. 2016). In the Iberian Peninsula, this species was introduced for the first time in the late $19^{\text {th }}$ century, but was spread mainly during middle 20th century in some high mountain lakes located in different mountain ranges (Doadrio 2002; Elvira and Almodovar 2001; Granados et al. 2006; Toro 2007), including Lake Grande de Peñalara, located in the Iberian Central Range.

For several decades, there has been an increasing trend to develop programs for the eradication of exotic fish, which have been introduced into aquatic ecosystems, with the aim of restoring the ecological balance of these ecosystems. Several and diverse eradication techniques have been used, obtaining varied results according to the type of ecosystem and the introduced species (Donaldson and Cooke 2016). In the Iberian Peninsula, the ecological impact of the allochthonous fish introduction in aquatic ecosystems has not yet been well studied, though the still scarce specific studies in rivers and lakes warn about the possible magnitude of this problem (García-Berthou et al. 2015). In Spain, so far, only one experience of eradication of an introduced fish (Cyprinus carpio) has been carried out with success, in two Mediterranean lowland lakes, obtaining promising results in the recovery of these ecosystems and their associated biological communities (Maceda-Veiga and Green 2017; Torres-Esquivias et al. 2009).

In 1992 a monitoring and restoration project on the Lake Grande de Peñalara alpine area (Central Iberian Range) was implemented by the regional Government (Toro and Granados 2002). This project included the removal of the introduced salmonid brook trout (Salvelinus fontinalis) in Lake Grande de Peñalara, with annual monitoring of the invertebrate community to control the recovery process previously, during, and after the fish removal.

Our main hypotheses were: 1 . Brook trout, an allochthonous fish species introduced in a small Iberian high mountain lake, would have modified during the nearly 30 years of presence the structure and composition of the aquatic invertebrate community, with the latter being its main food resource; 2. After brook trout removal, a recovery of the aquatic invertebrate community towards a community structure closer to a natural fishless condition, is expected; and 3. Changes in the aquatic invertebrate community would be mediated by the main biological and ecological traits that provide aquatic invertebrates better survival and colonization chances. 


\section{MATERIALS AND METHODS}

\subsection{Study site}

Lake Grande de Peñalara is a small and relatively shallow high mountain lake located in the National Park of Sierra de Guadarrama, in the Iberian Central Range (Spain), at 2016 m a.s.l. (Table 1 and Figure 1). It was formed by glacier overdeepening. The lake bottom is mainly silty, with relatively low organic matter content (13\%), and blocks, stones, pebbles and sandy material along the shores. No submerged macrophytes are present. The lake is discontinuous cold polymictic (according to Lewis Jr. 1983 classification), being ice covered during ca. 4 months. More detailed information of this lake and its catchment can be found in Granados et al. (2006), Toro and Granados (2002) and Toro et al. (2006).

This lake was originally fishless (Toro 2007), and brook trout was introduced for angling in the 70's. The lack of adequate and heterogeneous habitats for invertebrates' refuge, such as submerged macrophytes communities, could have facilitated a strong predation effect on large size and swimmer invertebrates after fish stocking, as described for other sites (Carlisle and Hawkins 1998; De Mendoza and Catalan 2010).

Re-colonization of the lake by aquatic invertebrates is very difficult by drifting processes since there is not any other pond or wetland located upstream in the lake catchment, and only one temporary small inlet creek can act as a possible source of macroinvertebrates. Nearest ponds or small lakes are located farther than 200-300 meters, though hydrologically unconnected from the lake (Figure 1).

\subsection{Fish eradication}

The eradication of brook trout in Lake Grande de Peñalara was conducted using 5 multi-mesh nylon gillnets (Nordic Survey Net), consisting of 12 panels (1.5 m height x $2.5 \mathrm{~m}$ long) of different size meshes (5, $6.25,8,10,12.5,15.5,19.5,24,29,35$ and $55 \mathrm{~mm}$ stretched net from knot to knot) in a standard randomised order (design according to Appelberg et al. 1995). They were set perpendicular to the lake shore during the whole year removing catch fish every few days (except during the winter period when the nets stayed under the ice cover for several months). Gill nets were removed, deep cleaned and placed again every 1 or 2 months. Nets were installed at the beginning of August 1999, ending by July 2004, two years after the last three fish were collected in spring 2002 (just after the ice-cover period), thus declaring the complete brook trout eradication according to criteria discussed by Tiberti et al. (2018). Although gillnetting is a more expensive and time consuming method than others like rotenone, it is very efficient and more ecologically friendly to be used in such small mountain lakes (Knapp and Matthews 1998).

\subsection{Sampling of aquatic invertebrates}

Sampling of benthic macroinvertebrates was performed at least annually from 1986 to 2018 (22 years, with 1 to 8 campaigns per year) during the ice-free period (Table 1). Samples were collected with D-nets (350 
$\mu \mathrm{m}$ mesh size) by sweeping the surface of stirred substrate up to $1 \mathrm{~m}$ depth during 30 minutes, from all the existing littoral habitats of the lake (silts, sands, gravels, rocks), in a proportion relative to its coverage. Zooplankton samples were collected from an inflatable boat or from the ice-cover over the deepest part of the lake ( $4.8 \mathrm{~m}$ deep) by taking 1-3 vertical hauls with a conical plankton net ( $55 \mu \mathrm{m}$ mesh size and $26 \mathrm{~cm}$ of diameter) from the lake bottom to the surface. Zooplankton sampling was performed at least annually from 1991 to 2013, with a variable number of campaigns every year (see Table 2), both during the ice covered and ice-free periods. Even though it has not been possible to carry out the same number of campaigns every year due to the lack of ongoing research funding projects during the 30 years of the study, the average numbers of pre- (9) and post- (17) eradication taxa (Figure 2) show that the possible differences in the sampling frequency each year did not affect the average value of taxa found.

Benthic macroinvertebrates and zooplankton samples were preserved in 4\% formalin from 1990 to 2004, subsequently with 70\% ethanol for macroinvertebrates and lugol for zooplankton (2005-2018). Taxa were identified to the lowest possible taxonomic level under stereo (10-40x) and inverted (10-100x) microscopes for macroinvertebrates and zooplankton, respectively, by using different taxonomic keys. The entire sample (sediment/water) was completely analysed for macroinvertebrates. For the zooplankton counting, the sample was divided into aliquots and up to 250 individuals for each group were counted for both rotifers and crustaceans, respectively, although counts are not available for all the years. In addition, we measured the length of a minimum of ten individuals for each stage of each species in each sample. The measurement of the body length was used as a surrogate of individual size.

\subsection{Biological indicators}

Macroinvertebrates biological and ecological traits have been used to assess the response and recovery of these communities after the eradication of brook trout in Lake Grande de Peñalara. According to Tachet et al. (2000), species, genus and family level can be used to describe the functional diversity (e.g., traits) of macroinvertebrate communities (Usseglio-Polatera et al. 2000). Each trait has different modalities with a score assigned to each taxon according to its affinity for that category, ranging from 0 ("no affinity") to a maximum value of 5 ("high affinity"), following a fuzzy coding approach (Chevenet et al. 1994; Tachet et al. 2000). The main advantage of the fuzzy coding procedure is that it allows the analysis of information from various sources and for intermediate scenarios of each category, transforming continuous data into categories (Aşan and Senturk 2012). A taxon could get scores for some or all codes for a trait. A trait profile (e.g. ecological) can be compared to a frequency distribution of the taxon's affinity for the different modalities of the concerned trait. Selected traits according to the information given by Chevenet et al. (1994) and Tachet et al. (2000) were: (i) those showing a potential relationship with the resistance or advantage to avoid predation by fish (size, preference of habitat and locomotion), (ii) those related to adaptation, and (iii) those linked to the ability to colonize new favourable habitats (life and reproduction cycles, aquatic stages and dispersal; Cavalli et al. 1997; Eggers 1982; Fitzmaurice 1979; Schilling et al. 2009; Knapp et al. 2001; Sánchez et al. 2007; Tiberti et al. 2014, 2018; Wattiez 1981), for all the taxa present in the lake, have been chosen. 


\subsection{Data analysis}

Benthic invertebrates and zooplankton assemblages' composition and richness before and after the eradication of brook trout were compared. A hierarchical cluster analysis (HCA) of year assemblage data (input dataset: Table 4 and Figure 6) was performed as the most suitable exploratory method, due to the low number of cases (22 years for macroinvertebrates and 16 for zooplankton) and taxa (45 for macroinvertebrates and 22 for zooplankton), many of them with only presence/absence data available (Gore 2000). HCA defines groups of years and taxa, and assigns group memberships based on the degree of similarity between observations, but it does not make any distinction between dependent and independent variables. Squared Euclidian Distance among taxa/years was adopted as a dissimilarity index, and Ward's minimum variance (Ward, 1963) as the most appropriate clustering method to maximize the significance of differences between clusters (Gore 2000).

For macroinvertebrates, a fuzzy correspondence analysis (FCA) (Chevenet et al. 1994) was used to analyse the relative affinity of the sampled years (before, during and after eradication) for the different categories of traits selected as indicators of the resistance to fish predation by fish and the ability to colonize and establish in the different lake habitats, respectively. It is based on information about taxa that assume several categories of the same trait with different degree of affinity (Dolédec and Chevenet 1994). This kind of analysis has been successfully used in previous studies for the assessment of changes in macroinvertebrate assemblages before and after experiencing different pressures (Brand and Miserendino 2014; Arce et al. 2014; Desrosiers et al. 2019). A matrix of years (equivalent to "samples")-traits was built-up by multiplying two matrixes: taxa-traits and taxa-years, by transforming the result to percentages (\%) of each modality for each year. This matrix years-traits represents the relevance of each trait and its modalities in the macroinvertebrate assemblage existing in that year, where the effect of the presence/absence of fish could play an important role. The R package Factoclass was used to combine factorial method (Chessel et al. 2004) and cluster analyses to perform the multivariate exploration on the data matrix (Pardo and Del Campo 2007), as well as to get a partition of the data set and the characterization of each of the classes.

Regarding the zooplankton composition, we checked the possible effects of fish presence and temporal variation, both annual and interannual, through redundancy analysis (RDA). We used the zooplankton composition in function of the fish presence, the month and the year. The fish presence was considered as a category by defining three periods: before, during and after eradication. The year and month were the sample was obtained were also considered as factors. Hellinger transformation was used for the data on species counts when considering the zooplankton composition for the analysis. The Euclidian distance was used.

In order to reveal possible differences in the zooplankton size as a function of fish presence in the lake and of the temporal variation, we performed ANOVA of the zooplankton lengths, both for the whole assemblage as well as for the different species, to seek differences among the pre-eradication period, the eradication period, and thereafter. We considered the temporal variation in the analysis by including again the sampling month and year as factors. For the whole assemblage analysis we also used the taxon and the 
developmental stage as factors. Moreover, we also performed ANOVAs to seek other differences in the composition of the zooplankton assemblages by analysing the differences in crustacean vs rotifers ratio.

Statistical analyses were performed using IBM SPSS Statistics (IBM Corp. Released 2016) for cluster analyses. RStudio (RStudio Team, 2018) was used for fuzzy correspondence analysis with the package Factoclass (Pardo and Del Campo, 2007), whereas for RDA the vegan package was used (Oksanen 2017).

\section{RESULTS}

\subsection{Brook trout eradication}

Once the eradication activities were started, the first year (1999) a total of 239 individuals were captured; the second year (2000) 318 were captured; the third year (2001) the catches were between 20-40 individuals (this number is approximate due to poor conservation of the fish after being trapped under the ice for several months during the winter period); and finally, the last 3 fish were collected in 2002, just after the ice-cover period. Gill nets remained installed until the summer of 2004 (July), without capturing any additional fish. After that date, no more fish were observed in the lake. Brook trout has been also removed from the lake outlet downstream (Bosch et al. 2019), so natural recolonization is not possible.

\subsection{Macroinvertebrate fauna changes}

The composition and richness of the macroinvertebrate assemblages changed during and after the eradication of brook trout in Lake Grande de Peñalara. Mean taxa richness per year increased from 9 in the years prior to eradication, to 18 during the eradication process, and to 22 in the subsequent fishless years, reaching a maximum of 27 taxa in 2011 (Table 3 and Figure 2). The absence data of a taxon in a given year should be considered as the taxon was not captured in the sampling campaigns, though its absence in the lake could not be demonstrated.

From the cluster analyses, Ward's dendrogram grouping years (Figure 3a) resulted into two major dissimilar clusters ( $\mathrm{Y} 1$ and $\mathrm{Y} 2)$ (rescaled distance cluster combine $=25)$, one of them $(\mathrm{Y} 2)$ divided into two relative dissimilar groups (rescaled distance cluster combine $=11$ ). All three were clearly separated by the fish presence/absence in the lake as follows: Y1. Years with presence of brook trout; Y21. Years during eradication process and first year after eradication, and Y22. Two or more years after eradication, without brook trout in the lake.

Ward's dendrogram for taxa (Figure 3b) resulted into two major dissimilar clusters (T1and T2) (rescaled distance cluster combine $=25$ ), both divided into two relative low dissimilar groups (rescaled distance cluster combine $=5$ and 3), related to frequency of appearance and to fish presence/absence. Group T1, characterized by high frequency taxa (continuous annual presence), is divided into two groups: T11. High frequency taxa and coexistence with fishes and after eradication; T12. High frequency taxa appearing during eradication and later. Instead, group T2, which always corresponds to the eradication process or later, is characterized by a low-medium frequency of appearance (discontinuous annual presence), and is 
divided into two groups: T21. Low frequency taxa with appearance since the first year of sampling (2001) during eradication process and later; T22. Low or medium frequency taxa with appearance mostly in 2002, during the eradication, and/or later. T22 can be divided into 5 groups with a low dissimilarity between them (rescaled distance cluster combine $=2$ ): T221, T222 and T223 include taxa with appearance mostly in 2002 and/or later (mostly 1-3 years). T224 includes taxa with appearance from the last two years of sampling during eradication process (2001-2002) to 4 years later (2006), and T225 includes taxa with appearance 6 years (2008) or later after eradication process.

Selected traits categories assignment for each taxa found in Lake Grande de Peñalara from 1986 to 2018 are shown in Table 5. Results of Fuzzy Correspondence Analysis (FCA) show that the information on the first 2 axis explains most of the variability (78.0\%) in traits and therefore, it is sufficient to analyse the first factorial plane (Figure 5). All traits categories (Figure 4a) are ordered along the first axis following different gradients and according to their affinity with the distribution of years grouping along the same first axis (Figure $4 b$ ). The years have been classified into three groups (Figure $4 b$ ), indicating a gradient of presence/absence of fish in the lake as follows: I. Before fish eradication II. Eradication period; III. After fish eradication. Figure 5 shows traits correlations with axis 1-2 in the FCA.

Regarding locomotion and the relation with substrate, taxa with crawler (u4), burrower (u5), interstitial (u6) or temporally attached (u7) habits showed a good adaptation to fish predation, and they are very related to the group of years with fish presence (group I). On the contrary, the categories of fliers (u1), surface swimmers (u2) and swimmers in open water (u3) are significantly related to the years after eradication. This trait shows the highest correlation rate (0.094) with the Axis 1 of the factorial plane (Figure 5). The microhabitats trait shows a similar response, though less marked, to the above mentioned locomotion and substrate related traits along the first axis (Figure 4a). The microhabitat categories that are characteristic and predominant in the lake, are located in the gradient of axis 1 related to the taxa found in years with fish presence: boulders, cobbles and pebbles (t1), gravels (t2), sands (t3), silt (t4) and twigs or roots (t7). However, the categories of the microhabitats trait that are related to the taxa that appeared in the years after fish eradication correspond to less frequent or often lacking habitats in the lake: beds of macrophytes and filamentous algae (t5), microphytes (t6), organic detritus and litter (t8), and mud (t9). With respect to dispersion mechanisms, this trait reaches the second highest correlation with first axis of the factorial plane (correlation rate $=0.022)$ (Figures 4 and 5 ) between taxa with aquatic passive dispersion (f1) or aerial passive dispersion (f3) for the years with the presence of brook trout, and between taxa with active aquatic dispersion (f2) and active aerial dispersion (f4) for the years after the eradication. The different aquatic stages in which a taxon can be found in the aquatic environment are also reflected in a gradient along axis 1. Thus, the aquatic stages of larvae (d2), and especially pupae (d3), are more typically the taxa which coexisted with fish. On the contrary, the forms of eggs (d1) and especially the aquatic adult stage (d4), are more representative of taxa which appeared in the lake after fish eradication. Short life cycles $(\leq 1$ year) (b1) and low number $(<1)$ of reproductive cycles per year (c1) are traits related to taxa coexisting with brook trout, although these traits do not show a high correlation with Axis 1 (0.003 and 0.007 respectively) (Figure 5). Finally, taxa size shows a weaker ordination in the factorial plane regarding the transition from 
fish presence to a fishless condition (correlation with Axis $1=0.005$ ) (Figure 5), with largest sizes (a4, a5 and a6) closer to years with fish presence, and smaller sizes (a1, a2 and a3) slightly closer to fishless years. A gradient somewhat more related to axis 2 (correlation rate $=0.007$ ) was found for this trait (Figure 5), which could represent a transition between the years of the eradication process (2001-2002) and the subsequent years with fish already eradicated. Thus, the attributes of large taxa sizes (a5 and a6) are located in the plane most related to the transition years of eradication, contrarily to the category of smaller size (a1) positioned in the opposite extreme of axis 2 .

\subsection{Zooplankton}

The annual richness of the zooplankton assemblages did not show any significant change when comparing the periods before (mean value $=9 ; n=6$ ) and after (mean value $=9.6 ; n=10$ ) the eradication of brook trout in Lake Grande de Peñalara (Figure 6). However, and regarding clustering analyses, Ward's dendrogram for years (Figure 7a) resulted into two major dissimilar clusters (Y1 and Y2) (rescaled distance cluster combine $=25)$, one of them (Y2) divided into two relative dissimilar groups Y21 and Y22) (rescaled distance cluster combine $=8$ ), all three with a significant evidence related with the presence/absence of fishes in the lake: Y1. Years with presence of brook trout; Y21. A group of 4 years which include one year before eradication, two following years just after eradication, and one year 9 years after eradication; and Y22. Three or more years after eradication, except the former, without brook trout in the lake.

Ward's dendrogram for taxa (Figure 7b) based on presence/absence data resulted into two major dissimilar clusters $(\mathrm{T} 1$ and $\mathrm{T} 2)($ rescaled distance cluster combine $=25)$, both divided into two relative low dissimilar groups (rescaled distance cluster combine $=5$ and 6 ), related to both the frequency of taxa appearance and presence/absence of fish. Group T1, is divided into two groups, and it is characterized by low (T11) or medium (T12) taxa appearance (not continuous annual presence): T11. Low or rare taxa, including 6 taxa which appeared only when fish were present, 3 taxa which appeared only when fish were absent, and 1 taxa which appeared both in years with presence and absence of fish; T12. Medium frequency taxa with appearance both in years with presence and absence of fish. Group T2 comprised species with almost continuous occurrence, and is divided into two subgroups: T21 includes species mainly appearing after the eradication of the fish; and T22 include taxa with very frequent or continuous appearance both before and after the eradication process.

Figure 6 also shows both the presence/absence data, as well as the absolute abundance of each zooplankton species in years when the samples were analysed quantitatively. Because only one year is available before eradication with quantitative data (1997) to be compared with data from the 10 years after eradication (2003-2012), a detailed analysis of these absolute abundance data has not been performed. Nevertheless, notable differences are observed for some species between the maximum annual abundance values $\left(\mathrm{n}^{\circ}\right.$ indiv. $/ \mathrm{m}^{3}$ ) reached after the eradication with the values found in 1997, when the brook trout was present in the lake. Ceriodaphnia reticulata had a density of $67,000 \mathrm{ind} . / \mathrm{m}^{3}$ at the end of the summer of 1997, and during the period 2003-2012 its density was never higher than 14,645 ind. $/ \mathrm{m}^{3}$. Similarly, Eucyclops 
serrulatus and Asplanchna priodonta, with abundances (ind. $/ \mathrm{m}^{3}$ ) of 4,100 and 22,600 in 1997, and maxima of 414 and 3,440 within the 10 years following eradication, respectively, dropped their abundance almost by an order of magnitude. Oppositely, species such as Tropocyclops prasinus or Keratella quadrata showed maximum values (ind. $/ \mathrm{m}^{3}$ ) of 6,650 and 11,900, respectively, in 1997, but reaching annual maxima of 75,400 and 98,100, respectively, in the period 2003-2012, nearly increasing by an order of magnitude.

Most of the zooplankton species showed noticeable interannual differences in their maximum density values during the 10 years following the eradication of the fish (Figure 6), with increases or decreases depending on the year. This, obviously, cannot be attributed to the presence or absence of the eradicated brook trout, but instead could be associated to other environmental or limnological changes, or to interactions with other species during a possible long term readjustment of the communities after fish eradication (e.g. time lags).

The RDA showed both seasonal and interannual differences in the composition of the zooplankton assembalges as both month and year resulted significant variables, whereas the time series period (defined by fish presence), was not significant. The RDA had a good performance $\left(r^{2}=0.32\right)$ just including these two temporal variables. We found that the four species that dominated the zooplankton composition, Polyarthra vulgaris, Keratella quadrata, Tropocyclops vulgaris and Ceriodaphnia reticulata, were associated to different months and years (Figure 8). Poliarthra vulgaris was related to spring months and mostly linked to the period previous to the eradication. Then, summer months were dominated by Keratella quadrata. Autumn samples showed the dominance of the crustaceans Tropocyclops vulgaris and Ceriodaphnia reticulata, and by the end of autumn and winter dominance turned to Keratella quadrata. As for the year, before the eradication the community was dominated by Keratella quadrata, during the eradication it moved towards a community with an increasing importance of the crustaceans. From 2003 to 2005, Keratella quadrata and Ceriodaphnia reticulata were dominant, whereas from 2006 to 2009 Polyarthra vulgaris dominated. Then it moved to a crustacean dominance in 2011 and 2012.

Five new rotifer taxa were exclusively found after fish eradication (Trichotria tetractis, Colurella/Euchlanis, Filinia opoliensis, Kellicotia longispina and Lecane lunaris), whereas other five taxa disappeared (Polyarthra remata, P. dolichoptera, Filinia longiseta, Tetramastix opoliensis and Brachionus calyciflorus). Polyarthra vulgaris showed a continuous presence in the lake after fish removal but it was only found in one of the years before eradication, whereas $P$. dolichoptera and $P$. remata were only present during fish stocking, then they disappeared after fish eradication.

Globally the zooplankton assemblage was significantly smaller (shorter length, $\mathrm{p}<0.001$ ) before fish eradication (mean length $157 \mu \mathrm{m}$ ) than during the eradication period (mean length $185 \mu \mathrm{m}$ ) and thereafter (mean length $208 \mu \mathrm{m}$ ). Additionally, there were significant differences among years. In years 2003, 2007 and 2009, the average lengths were significantly bigger, whereas in 2004 and 2005 they were significantly smaller. The crustacean/rotifer ratio was also significantly higher after the fish removal (6.8\% more than the mean $\mathrm{p}<0.001$ ), which could also explain the bigger sizes after eradication since crustaceans are 
generally bigger than rotifers. Furthermore, we also found significant differences in species sizes for the different periods. For instance, we found significant differences $(\mathrm{p}<0.001)$ in the length of females of the copepod Eucyclops serrulatus, the bigger zooplankton species in the lake, with a mean length before the eradication of $836 \mu \mathrm{m}$, later on of $932 \mu \mathrm{m}$. However, other species of smaller sizes showed no significant size changes.

\section{DISCUSSION}

The analysis of trait profiles and presence/absence data of invertebrate taxa found in Lake Grande de Peñalara, before, during and after the eradication of introduced alien brook trout, helps to interpret the changes in the composition of their communities throughout the eradication process, as related to the fish predatory pressure. Feeding habits of the brook trout in lake ecosystems are mainly benthic-littoral (Power et al. 2002), where the habitat heterogeneity and inputs of allochthonous fauna as an important food source (Rolla et al. 2018) are high. Lake Grande de Peñalara is a relatively small $\left(6,964 \mathrm{~m}^{2}\right)$ and shallow $(4.8 \mathrm{~m}$ maximum depth) lake, where the proportion of littoral habitat is very high compared to that of pelagic habitat. Therefore, the response of the assemblages of benthic or littoral invertebrates is expected to be very rapid in response to changes in the levels of pressures such as fish predation.

The macroinvertebrates richness ( $\mathrm{n}^{\mathrm{o}}$ of taxa) (Figure 2) already showed a clear annual increase during the brook trout eradication works in 2001 and 2002. Most fish catches occurred in 1999 (239 ind.) and 2000 (318 ind.), and consequently predatory pressure radically decreased from 2001, when only a few dozen individuals were captured, and 2002, when the last 3 fish were caught. The macroinvertebrate assemblages of the lake during the period where brook trout inhabited the lake included only 13 taxa, 9 of them with a repeated appearance every sampled year. However, to avoid sampling biases, we have considered a taxon as absent when it did not appear over a period of at least 10 years (e.g. taxa that are not found in the presence of brook trout: Acilius, Berosus, Gerris), whereas we considered as an unproven absence when a certain taxon appeared intermittently in the 10 years period (e.g., for the post-eradication period, taxa that are found only a few years), which could be due to two reasons: a) the difficulty of capturing as being elusive or scarce (e.g. Gyrinus, Dytiscus); b) the concerned taxon reaches sporadically the lake but does not colonize it due to the difficulty to find a suitable habitat or adequate conditions (e.g. Amphinemura, Aeshnidae).

Macroinvertebrates classification (Figure 3b) shows a group very well defined by their biological and ecological traits, Group T11, which confers them a good adaptation to the presence of predatory fish. These are burrower and have interstitial habits (Chironomidae, Oligochaeta, Pisidium, Sialis) or crawler (Allogamus, Athripsodes, Habrophlebia, Limnephilinae, Oulimnius) locomotion and substrate beneficial habits helping to hide from fish vision (Knapp et al. 2001; Tiberti et al. 2014). Chironomidae are usually reported as a frequent and high density group in sediments of alpine lakes where fish are present (Gilinsky 1984; Lafrancois et al. 2003). On the contrary, swimmers are potentially one of the more sensitive groups to fish predation. Fliers (u1), surface swimmers (u2) and open water swimmers (u3) are significantly related to the years after the eradication, given that these are unfavourable traits which would allow brook trout 
predation. Similarly, Tiberti et al. (2018) reported an increase in swimmers and clingers in alpine lakes of the Western Italian Alps after the eradication of brook trout. Moreover, in eastern North America, Gaenzle et al. (2009) found more abundant active and free-swimming macroinvertebrate taxa in fishless lakes, whereas Evans (1989) recorded the disappearance of some Heteroptera (i.e. notonectids and corixids) and coleoptera larvae (Dytiscidae) just 3 months after the introduction of brook trout in a lake. On the other hand, Heteroptera (e.g. Artocorixa, Corixa, Gerris, Hesperocorixa, Notonecta, Pleidae, Sigara, Veliidae) have a high capacity of active dispersion, both aerial (f4) and aquatic (f2), which facilitates their rapid colonization once the eradication was effective in Lake Grande de Peñalara. Most of them were absent or rare during fish presence because of their swimmer habits (u2 and u3) in surface (e.g. Gerris, Gyrinus) and open waters (other Heteroptera), making them very visible to fish, but they appeared as the first group of lake colonizers at the beginning of the eradication process (Groups T12, T221 and T222 in Figure 3b), being always present thereafter. The absence of macrophytes in this lake, which would serve as a spatial refuge from fish predation, probably precluded the presence of these swimmer species as demonstrated by other authors (Gilinsky 1984; Leppä et al. 2003). For instance, in a study of 82 alpine lakes in the Pyrenees mountain range (NE Iberian Peninsula), the presence of salmonids and macrophytes were more decisive for the distribution of dytiscids (swimming Coleopterans) than temperature (De Mendoza et al. 2012). In this study, the dytiscid Agabus bipustulatus, a typical swimmer with a wide thermal distribution on the Iberian Peninsula, was mainly found in cold high mountain fishless lakes. In the Southern Lake Grande de Peñalara, located in a warmer climate than Pyrenean lakes, A. bispustulatus (and also A. nebulosus) were only found when eradication of brook trout had already started, but they appeared almost constantly thereafter, which shows its high sensitivity to fish predation. The capacity for aerial dispersion was also very important for some of the new colonizers, since there are no significant inlets to the lake allowing drifting processes. The aerial dispersal mode would also play an important role in the sensitivity of macroinvertebrate taxa to be captured by adult fish before the eradication. Accordingly, Sánchez et al. (2007) observed a large number of aerial preys consumed by fish with respect to the benthic ones in five alpine lakes in the nearby Gredos Mountains (Iberian Central Range), especially by adult fish.

The macroinvertebrate taxa included in groups T224 and T225 (Figure 3b) appeared in the lake 4 to 6 years after the complete eradication of the brook trout, respectively. All of them were relatively rare or with a low frequency of appearance in these years, and their traits affinities for microhabitats were related to macrophytes and filamentous algae (t5), microphytes (t6), organic detritus and litter (t8) and mud (t9), all of them being scarce or lacking in the lake. Contrarily to other aquatic insects (e.g. Chironomidae, some mayflies, stoneflies or caddishflies) with a limited dispersal potential between alpine lakes (Bitušík et al. 2017), the dispersal mechanisms of these taxa (eg. Acilius, Aeshnidae, Artocorixa, Berosus, Hemisphaera, Hydrochus, Hydrophilidae) are mainly aerial and active (f4), most of them with winged adult stages. Their sporadic appearances probably correspond to a continuous flux of individuals which reach the lake from short distances (nearby ponds in the area) but do not effectively colonize and reproduce there (Hawkins et al. 2000) due to the lack of suitable habitats. They continuously contribute to the maintenance of a higher richness after the eradication of brook trout. These taxa could therefore be considered as suitable indicators of environmental recovery of these types of aquatic ecosystems (Resh et al. 2005). Schilling et al. (2009) 
have pointed out that some of the T22 Group families (i.e. Dytiscidae, Gyrinidae, Aeshnidae, Corixidae or Notonectidae) which were recorded in Lake Grande de Peñalara after fish eradication, are robust indicators of fish absence in lakes. Therefore, they should not be ignored nor excluded in community analyses as outliers, although some authors (Hawkins et al. 2000) consider them unimportant to quantify the resistance and resilience of the faunal community.

Contrasting to the macroinvertebrates, the richness of the zooplankton taxa kept similar annual mean values (Figure 6) before and after the eradication of the brook trout in Lake Grande de Peñalara. These results are in accordance with some studies in alpine lakes of the Swiss (Winder et al. 2001) and Italian (Stoch et al. 2019) Alps, where fish presence was excluded as a main factor explaining the occurrence or absence of large zooplankton species, and in Western Canadian mountain lakes, where Donald et al. (2001) compared fishless lakes with lakes where salmonids were introduced, pointing out the low planktivorous efficiency of the brook trout. Even though an eradication experience in Western Italian Alps (Tiberti et al. 2018) showed that the biomass of larger zooplankton taxa increased after fish eradication, our results reveal how, in Lake Grande de Peñalara, large zooplankton species like Tropocyclops prasinus, Ceriodaphnia sp. or Alona sp. did not show any permanent increase trend in their abundance after fish eradication.

Additionally, no new species of cladocerans nor copepods appeared after fish eradication, and, although the data on abundance are scarce for the period prior to the eradication, the annual fluctuations in the abundance of most of these taxa after fish removal reflect that other environmental variables could be governing the time course of the zooplankton taxa. Although large cladocerans, such as Daphnia or calanoid copepods, are species with possibilities of recovery from diapausing eggs (Hairston et al. 1995; McNaught et al. 1999), no new species after fish eradication appeared in Lake Grande de Peñalara, which would confirm the relative insensibility of zooplankton to brook trout predation.

Several authors reported increases in rotifer abundance after lake fish stocking due to fish predation on large crustaceans (McNaught et al. 1999). In our study we have not enough data on rotifers abundance prior to fish eradication, but the appearance of 4 new taxa (Trichotria tetrctis, Colurella/Euchlanis, Filinia opoliensis and Kellicotia longispina) and dissapearance of 5 taxa (Polyarthra remata, P. dolichoptera, Filinia longiseta, Tetramastix opoliensis and Brachionus calyciflorus) after fish eradication have been recorded, showing a significant change in the composition of rotifers assemblages in the lake. Among the rotifer species found in the lake through the whole studied period, Polyarthra vulgaris, Asplanchna priodonta, Kellicotia longispina and Keratella quadrata are also very common species in other European high mountain lakes (Catalan et al. 2009; Miracle, 1978; Tonolli and Tonolli, 1951). Keratella quadrata is the most abundant and perennial (pre- and post-eradication) rotifer species in Lake Grande de Peñalara. It has also been reported as the most abundant rotifer in other high mountain lakes in the Iberian Central Range (Boavida and Gliwicz 1996, in Serra da Estrela; Toro and Granados 2001, in Sierra de Gredos).

There is not any clear relationship between the changes of every single rotifer species and fish effects. The new and continuous record of Kellicotia longispina after fish eradication fits to the results obtained by 
Schindler and Parker (2002) in lakes from the Canadian Rockies, where this species was dominant before fish introductions in the $1960 \mathrm{~s}$, but the referred study contrasted with the opposite results obtained by McNaught et al. (1999) for a small alpine lake in the Canadian Rocky Mountains, where this species was abundant during fish stocking, and disappeared after fish removal, being replaced by Polyarthra dolichoptera, which in turn was present in Lake Grande de Peñalara only during the fish stocking period. Similarly, the absence of $P$. dolichoptera after fish removal was observed by Stenson $(1982,1983)$ in a Swedish lake, where $P$. vulgaris remained after fish eradication. Changes in phytoplankton community and oxygen content and temperature were pointed as possible reasons for these changes. P. dolichoptera, a coldstenothermal species, would tolerate low oxygen levels in water column (Stenson 1983) during a higher productivity period with fish presence in Lake Grande de Peñalara, and $P$. vulgaris could have increased its population with the improvement of water quality and oligotrophy trend of the lake, and the phytoplankton changes after fish eradication shown by Toro and Granados (2002) and Toro et al. (2006). Therefore, some changes in zooplankton composition and structure in Lake Grande de Peñalara after brook trout eradication could be more related to indirect effects of fish removal such as shifts in phytoplankton composition, productivity, and trophic status, rather than to the effects of direct predation. Since rotifers can be good indicators of the lake trophic status (Berzins and Pejler 1989), the disappearance of species indicating a higher trophic status, such as Brachionus sp. and Filinia longiseta (Ejsmont-Karabin 2012; Gannon and Stemberger 1978; Velasco et al. 2005) could be related to an improvement in the trophic status of the lake after fish eradication.

Although zooplankton did not show important changes in species richness, differences in the composition could be found, with a predominance of rotifers over crustaceans before and during the eradication, whereas the crustaceans increased their relative importance after fish eradication. Equally, Knapp (2001) and Tiberti et al. (2018) found that the abundances of the big size crustaceans were lower in fish stocked lakes, whereas small crustaceans and rotifers were more abundant. In these lakes, predation by brook trout showed important effects on bigger zooplankton, especially in those exceeding $1 \mathrm{~mm}$ length. In Lake Grande de Peñalara, the big species did not exceed this length, and therefore the impact of brook trout could have been more limited. However, some changes could be seen after the eradication, as the mean of the lengths of the community individuals increased due to both the increase in size of the biggest species and to the increasing dominance of crustaceans over the rotifers.

Resilience of zooplankton species is not yet well established. Some authors have pointed to a high resilience due to their high dispersal rates (Louette and Meester 2005), even higher for cladocerans than for copepods (McNaught et al. 1999), as well as by its capacity to keep resting eggs in sediments (Parker et al. 1996). Instead, Donald et al. (2001) suggested an average of 19 years to recover the original zooplankton assemblages after fish removal, arguing difficulties for recovery by the physical dispersal barriers in mountain ranges. Aspects like predation by macroinvertebrates on zooplankton, the length of fish permanence (long residence time would decrease the size of the egg bank of sensitive taxa in the sediments), or low lake depths (a deeper lake would facilitate the coexistence of fishes and large zooplankton species providing refuge in deep habitats), have been suggested as relevant factors for the resilience of the 
zooplankton assemblages (Donald et al. 1994; Knapp et al. 2001; Knapp and Sarnelle 2008; McNaught et al. 1999). Unfortunately, there are no similar reference sites with and without fishes in Lake Grande de Peñalara surroundings with available data to be compared and testing these hypotheses.

The lack of information on zooplankton composition prior to the fish stocking in Lake Grande de Peñalara makes it difficult to know if a natural state is reached after fish removal, or if fish stocking did not affect zooplankton community. A study on feeding ecology of brook trout in five alpine lakes in the nearby Sierra de Gredos (Iberian Central Range, ca. $130 \mathrm{~km}$ from Lake Grande de Peñalara) showed a diet composition based mainly on macroinvertebrates, with no record of crustaceans on a total of 49 stomachs analysed (Sánchez et al. 2007). However, this study was carried out just in the summer months, when the food resource is mainly composed of macroinvertebrates, while other authors (Cavalli et al. 2001) have reported a fish diet in alpine lakes based also on zooplankton (copepods) during the ice cover period. We do not know if any large zooplankton species (e.g. large crustaceans) with predatory capacity on smaller crustaceans or rotifers (McNaught et al. 1999) was present before fish stocking, which may not have returned to the lake after fish removal. If these large species were present, the current lack of these top predators in the food chain could hinder the reaching of an original equilibrium in the zooplankton composition. For instance, Winder et al. (2003) observed that the composition and relative dominance of some zooplankton species under fish predation in a high mountain Swiss lake were determined by the food web structure (including invertebrate predation or zooplankton competition) and the trophic status. According to previous experiences, it is not expected to reach a stability in the establishment of a community structure that matches the one hypothetically existing prior to the fish introduction in a period of at least between 10 (McNaught et al. 1999; Schindler and Parker, 2002) to 19 (Knapp et al. 2001) years. Although there is no clear evidence of significant changes in the zooplankton assemblages before and after the eradication of the brook trout in Lake Grande de Peñalara, the period of our study was already within this range, but changes should already have occurred or, at least, should have shown evident trends, if any. Likewise, Symons and Shurin (2016) found similar zooplankton assemblages in lower elevation fishcontaining and fishless lakes, while high-elevation lakes showed different communities with and without fishes. Higher summer temperatures in this Mediterranean high mountain lake type, in comparison with higher latitude lakes, could also be a factor influencing this apparently similitude before and after eradication in Lake Grande de Peñalara.

Because Grande de Peñalara is a small and relatively shallow lake, benthic habitats predominate over an almost non-existent pelagic area, which could be a reason of the absence of large pelagic crustaceans typical from deeper high mountain lakes (i.e. Daphnia species), at any period before, during, and after fish stocking (except two samples with D. longispina in 1996 and 2003). Because of aspects such as the small size, the simple habitats displayed in the lake, the low diversity of the zooplankton community, and the simplicity of the food web of this alpine ecosystem, higher sensibility (or fragility) to the introduction of a top predator in the food web would be expected (Cavalli et al. 2001; Knapp et al. 2005). This, together with the low resilience shown by zooplankton, would mean that the impact of the introduction of fish on biological communities in these types of lakes, in addition to being significant, would last longer than desired. 
Additionally, it is interesting to consider the possibility of a process of adaptability of the ecosystem (i.e. considering the zooplankton community) instead of a resilience type dynamics, if the disturbance caused by brook trout is long enough in time to drive to a different end that the pre-disturbance state (Müller et al. 2016). In such a case, no future short or medium-term shifts towards a hypothetically previous state would be expected, and the ecosystem could go towards a different, and maybe, less stable organization, or return to the baseline on the long term, which could take decades (Spears et al. 2017).

Finally, recent climate warming, with the already registered reduction in cold extremes and moderate precipitation decrease in the Iberian Peninsula in the last decades (Brunet et al. 2007; Vicente-Serrano et al. 2017) could also have affected the response of biological communities and lake food web structure towards an unexpected state under predation pressure (Symons and Shurin 2016) and perhaps also after fish eradication. Warming affects metabolism and trophic interactions in lakes, and it is suspected to reduce the resilience of food webs to introduced predators, which eliminate the large size zooplankton species, diminishing the capacity of species replacement to buffer the fish effect (Symons and Shurin 2016). Shallowness, together with the small lake and catchment sizes, added to the low topographic shading in Lake Grande de Peñalara, are factors that make this lake very sensitive to climate warming (Hamerlík et al. 2014; Novikmec et al. 2013). The maintenance of a long-term biological and limnological monitoring will be essential to evaluate any of these hypotheses and know the real evolution of the lake ecosystem.

In summary, according to the data obtained in this study, after the eradication of a salmonid introduced into a small mountain lake in southwestern Europe, aquatic invertebrate's communities showed different degrees of recovery. Very early changes have been observed since the beginning of eradication in macroinvertebrate assemblages (especially in swimmers species) towards richer communities, being probably similar to those that would be found before fish introduction, showing a high recovery capacity due to the dispersal abilities of the already extinct taxa due to fish predation. On the contrary, zooplankton has not undergone significant changes that could be directly related to the introduction and eradication of the brook trout, displaying either a low sensitivity to fish predation, or a very low recovery capacity, since a response and return to its theoretical original conditions would be expected in the studied period exceeding 10 years after eradication. However, rotifer composition has shown changes, but apparently more related to water quality (i.e. trophic status) or other environmental variables as a possible indirect consequence of fish eradication, and zooplankton assemblage was significantly smaller in length before the fish eradication than during the eradication period and after. Further studies are needed to deepen these hypotheses, by analysing the evolution of the biological communities in relation to available limnological and environmental data. Palaeolimnological studies of subfossil remains of zooplankton species (e.g. cladocerans) in this lake, or invertebrate communities' surveys in nearby fishless lakes, would be essential to address the assessment of the ecological resilience of these southern-European high mountain lakes. 


\section{ACKOWLEDGEMENTS}

This work has been supported by the National Park of Sierra de Guadarrama (Regional Government of Madrid). Work by A.C. is currently funded by the project CLIMAWET (CGL2015-69557-R). The authors are very grateful for their help in the taxonomic determinations to Andrés Mellado (macroinvertebrates) and Juan José Aldasoro, Manuel García Sánchez-Colomer and Santiago Robles (zooplankton), and for their assistance in statistical analysis to Andrés Mellado, Jorge R. Sánchez and Ignacio González.

\section{REFERENCES}

Aguilera X, Declerck S, De Meester L, Maldonado M, Ollevier F (2006) Tropical high Andes lakes: A limnological survey and an assessment of exotic rainbow trout (Oncorhynchus mykiss). Limnologica 36: 258-268.

Appelberg M, Berger HM, Hesthagen T, Kleiven E, Kurkilahti M, Raitaniemi J, Rask M (1995) Development and intercalibration of methods of Nordic freshwater fish monitoring. Water Air and Soil Pollution 85:883-888

Arce E, Archaimbault V, Mondy CP, Usseglio-Polatera P (2014) Recovery dynamics in invertebrate communities following water-quality improvement: taxonomy- vs trait-based assessment. Freshwater Science 33:1060-1073

Aşan Z, Senturk S (2012) An application of fuzzy coding in Multiple Correspondence Analysis for transforming data from continuous to categorical. Journal of multiple-valued logic and soft computing 18:355-370

Berzins B, Pejler B (1989) Rotifer occurrence and trophic degree. Hydrobiologia 182:171-180

Bitušík P, Svitok M, Novikmec M, Trnková K, Hamerlík L (2017) Biological recovery of acidified alpine lakes may be delayed by the dispersal limitation of aquatic insect adults. Hydrobiologia 790:287298

Boavida MJ, Gliwicz M (1996) Limnological and biological characteristics of the alpine lakes of Portugal. Limnetica 12: 39-45

Bosch J, Bielby J, Martin-Beyer B, Rincón P, Correa-Araneda F, Boyero L (2019) Eradication of introduced fish allows successful recovery of a stream-dwelling amphibian. PLoS ONE 14(4): e0216204.

Bradford DF, Cooper SD, Jenkins Jr TM, Kratz K, Sarnelle O, Brown AD (1998) Influences of natural acidity and introduced fish on faunal assemblages in California alpine lakes. Canadian Journal of Fisheries and Aquatic Sciences 55:2478-2491

Brand C, Miserendino ML (2014) Biological traits and community patterns of Trichoptera at two Patagonian headwater streams affected by volcanic ash deposition. Zoological Studies, 53, 1.

Braña F, Frechilla L, Oriazola G (1996) Effects of introduced fish on amphibians assemblages in mountian lakes of Northern Spain. Herpetological Journal 6:145-148

Brendonck L, De Meester L (2003) Egg banks in freshwater zooplankton: evolutionary and ecological archives in the sediment. Hydrobiologia 491:65-84

Brunet M, Jones PD, Sigro J, Saladie O, Aguilar E, Moberg A, Della-Marta PM, Lister D, Walther A, Lopez D (2007) Temporal and spatial temperature variability and change over Spain during 1850-2005. Journal of Geophysical Research 112 (D12117). ISSN 2156-2202 
Carlisle DM, Hawkins CP (1998) Relationships between invertebrate assemblage structure, 2 Trout species, and habitat structure in Utah mountain lakes. Journal of the North American Benthological Society $17: 286-300$

Catalan J, Grazia Barbieri M, Bartumeus F, Bitusik P, Botev I, Brancelj A, Cogalniceanu D, Manca M, Marchetto A, Ognjanova-Rumenova N, et al (2009) Ecological thresholds in European alpine lakes. Freshwater Biology 54:2494-2517

Cavalli L, Chappaz R, Bouchard P, Brun G (1997) Food availability and growth of the brook trout, Salvelinus fontinalis (Mitchill), in a French Alpine lake. Fisheries Management and Ecology 4:167-177

Cavalli L, Miquelis A, Chappaz R (2001) Combined effects of environmental factors and predator-prey interactions on zooplancton assembalges in five high alpine lakes. Hydrobiologia 455:127-135

Chessel D, Dufour AB, Thioulouse J (2004) 'The ade4 Package - I: Onetable Methods', R News 4:5-10

Chevenet F, Dolédec S, Chessel D (1994) A fuzzy coding approach for the analysis of long-term ecological data. Freshwater Biology 31:295-309

De Mendoza G, Catalan J (2010) Lake macroinvertebrates and the altitudinal environmental gradient in the Pyrenees. Hydrobiologia 648:51

De Mendoza G, Rico E, Catalan J (2012) Predation by introduced fish constrains the thermal distribution of aquatic Coleoptera in mountain lakes. Freshwater Biology 57:803-814

Desrosiers M, Usseglio-Polatera P, Archaimbault V, Larras F, Méthot G, Pinel-Alloul B (2019) Assessing anthropogenic pressure in the St. Lawrence River using traits of benthic macroinvertebrates. Science of the Total Environment 649:233-246

Doadrio I (2001) Atlas y Libro Rojo de los Peces Continentales de España. Dirección General de Conservación de la Naturaleza-Consejo Superior de Investigaciones Científicas. Madrid. https://www.miteco.gob.es/es/biodiversidad/temas/inventarios-nacionales/inventario-especiesterrestres/inventario-nacional-de-biodiversidad/ieet_peces_atlas.aspx

Dolédec S, Chevenet F (1994) ‘Fuzzy correspondence analysis’. ScienceDirect 158:1-20

Donald DB, Stewart R, Mayhood DW (1994) Coexistence of fish and large Hesperodiaptomus species (Crustacea: Calanoida) in subalpine and alpine lakes. Canadian Journal of Zoology 72:259-261

Donald DB, Vinebrooke RD, Anderson RS, Syrgiannis J, Graham MD (2001) Recovery of zooplankton assemblages in mountain lakes from the effects of introduced sport fish. Canadian Journal of Fisheries and Aquatic Sciences 58:1822-1830

Donaldson LA, Cooke SJ (2016) The effectiveness of non-native fish eradication techniques in freshwater ecosystems: a systematic review protocol. Environmental Evidence 5:12

Eggers DM (1982) Planktivore preference by prey size. Ecology 63:381-390

Ejsmont-Karabin J (2012) The usefulness of zooplankton as lake ecosystem indicators: rotifers trophic state index. Polish Journal of Ecology 60:339-350

Elvira B, Almodóvar A (2001) Freshwater fish introductions in Spain: facts and figures at the beginning of the 21 st century. Journal of Fish Biology 59:323-331

Evans RA (1989) Responses of limnetic insect populations of two acidic, fishless lakes to liming and brook trout (Salvelinus fontinalis) introductions. Canadian Journal of Fisheries and Aquatic Sciences 46:342-351 
Ficke AD, Peterson DP, Janowsky B (2009) Brook trout (Salvelinus fontinalis): a Technical Conservation Assessment. USDA Forest Service, Rocky Mountain Region. http://www.fs.fed.us/r2/projects/scp/assessments/brooktrout.pdf. Accessed 26 May 2019

Gacia E, Buchaca T, Bernal-Mendoza N, Sabás I, Ballesteros E, Ventura M (2018) Non-native minnows threaten quillwort populations in high mountain shallow lakes. Frontiers in Plant Science 9:329. doi: $10.3389 /$ fpls.2018.00329

Gannon JE, Stemberger RS (1978) Zooplankton (especially crustaceans and rotifers) as indicators of water quality. Transactions of the American Microscopical Society 97:16-35

García-Berthou E, Almeida D, Benejam L, Magellan K, Bae MJ, Casals F, Merciai R (2015) Impacto ecológico de los peces continentales introducidos en la Península Ibérica. Ecosistemas 24:84-89

Gilinsky E (1984) The role of fish predation and spatial heterogeneity in determining benthic community structure. Ecology 65:455-468

Gliwicz ZM (1980) Extinction of planktonic cladoceran species from alpine lakes stocked with fish planktivores. In: Horie S (ed) Paleolimnology of Lake Biwa and the Japanese Pleistocene, V. 8. Kyoto University, pp 3-22

Gliwicz ZM, Rowan M (1984) Survival of Cyclops abyssorum tatricus (Copepoda, Crustacea) in alpine lakes stocked with planktivorous fish. Limnology and Oceanography 29:1290-1299

Gore P (2000) Cluster Analysis. In: Tinsley H, Brown S (eds) Handbook of Applied Multivariate Statistics and Mathematical Modeling, Academic Press, New York, pp 297-321

Granados I, Toro M, Rubio-Romero A (2006) Laguna Grande de Peñalara, 10 años de seguimiento limnológico. Comunidad de Madrid, Consejería de Medio Ambiente y Ordenación del Territorio, Dirección General del Medio Natural, Madrid

Hairston NG, Van Brunt RA, Kearns CM, Engstrom DR (1995) Age and survivorship of diapausing eggs in a sediment egg bank. Ecology 76:1706-1711

Hamerlík L, Svitok M, Novikmec M, Očadlík M, Bitušík P (2014) Local, among-site, and regional diversity patterns of benthic macroinvertebrates in high altitude waterbodies: do ponds differ from lakes?. Hydrobiologia 723:41-52

Hawkins CP, Norris RH, Gerritsen J, Hughes RM, Jackson SK, Johnson RK, Stevenson RJ (2000) Evaluation of the use of landscape classifications for the prediction of freshwater biota: synthesis and recommendations. Journal of North American Benthological Society 19:541-556

IBM Corp. Released 2016. IBM SPSS Statistics for Windows, Version 24.0. Armonk, NY: IBM Corp

Karas N (1997) Brook trout. Lyons and Burford, New York

Knapp RA, Boiano DM, Vredenburg VT (2007) Removal of nonnative fish results in population expansion of a declining amphibian (mountain yellow-legged frog, Rana muscosa). Biological Conservation $135: 11-20$

Knapp RA, Hawkins CP, Ladau J, McClory JG (2005) Fauna of Yosemite national park lakes has low resistance but high resilience to fish introductions. Ecological Applications 15:835-847

Knapp RA, Matthews KR (1998) Eradication of nonnative fish by gill netting from a small mountain lake in California. Restoration Ecology 6:207-213

Knapp RA, Matthews KR, Sarnelle O (2001) Resistance and resilience of alpine lake fauna to fish introductions. Ecological Monographs 71:401-421 
Knapp RA, Sarnelle O (2008) Recovery after local extinction: factors affecting re-establishment of alpine lake zooplankton. Ecological Applications 18:1850-1859

Leavitt PR, Schindler DE, Paul AJ, Hardie AK, Schindler DW (1994) Fossil Pigment Records of Phytoplankton in Trout-stocked Alpine Lakes. Canadian Journal of Fisheries and Aquatic Sciences 51:2411-2423

Leppä M, Hämäläinen H, Karjalainen J (2003) The response of benthic macroinvertebrates to whole-lake biomanipulation. Hydrobiologia 498:97-105

Lewis WM Jr (1983) A revised classification of lakes based on mixing. Canadian Journal of Fisheries and Aquatic Sciences 40:1779-1787

Lafrancois BM, Carlisle DM, Nydick KR, Johnson BM, Baron JS (2003) Environmental characteristics and benthic invertebrate assemblages in Colorado mountain lakes. Western North American Naturalist 63:137-154

Louette G, Meester LD (2005) High dispersal capacity of cladoceran zooplankton in newly founded communities. Ecology 86:353-359

Maceda-Veiga A, López R, Green AJ (2017) Dramatic impact of alien carp Cyprinus carpio on globally threatened diving ducks and other waterbirds in Mediterranean shallow lakes. Biological Conservation 212: 74-85

McNaught AS, Schindler DW, Parker BR, Paul AJ, Anderson RS, Donald DB, Agbeti M (1999) Restoration of the food web of an alpine lake following fish stocking. Limnology and Oceanography 44:127-136

Magnea U, Sciascia R, Paparella F, Tiberti R, Provenzale A (2013) A model for high-altitude alpine lake ecosystems and the effect of introduced fish. Ecological Modelling 251:211-220

Miracle R (1978) Composición específica de las comunidades zooplanctónicas de 153 lagos de los Pirineos y su interés biogeográfico. Oecologia aquatica 3:167-191

Miró A, Ventura M (2015) Evidence of exotic trout mediated minnow invasion in Pyrenean high mountain lakes. Biological Invasions 17:791-803

Müller F, Bergmann M, Dannowski R, Dippner JW, Gnauck A, Haase P, Jochimsen MC, Kasprzak P, Kröncke I, Kümmerlin R, Küster M, Lischeid G, Meesenburg H, Merz C, Millat G, Müller J, Padisák J, Schimming CG, Schubert H, Schult M, Selmeczy G, Shatwell T, Stoll S, Schwabe M, Soltwedel T, Straile D, Theuerkauf M (2016) Assessing resilience in long-term ecological data sets. Ecological Indicators 65:10-43

Nelson JS, Paetz MJ (1992) The Fishes of Alberta. 2nd Edition. The University of Alberta Press, Edmonton, Alberta (Canada)

Novikmec M, Svitok M, Kočický Š, Bitušik P (2013) Surface water temperature and ice cover of Tatra mountains lakes depend on altitude, topographic shading, and bathymetry. Arctic, Antarctic, and Alpine Research 45:77-87

Oksanen JF, Blanchet, FG, Friendly, M, Kindt, R, Legendre P, McGlinn D, Minchin PR, O'Hara B, Simpson GL, Solymos P, Stevens H, Szoecs E, Wagner H (2017) 'vegan'. Community Ecology Package. R. Package Version 2.4-2

Pardo CE, Del Campo PC (2007) Combinación de métodos factoriales y de análisis de conglomerados en R: el paquete FactoClass. Revista Colombiana de Estadística 30:231-245

Parker BR, Schindler DW, Donald DB, Anderson RS (2001) The effects of stocking and removal of a nonnative salmonid on theplankton of an Alpine lake. Ecosystems 4:334-345 
Parker BR, Wilhelm FM, Schindler DW (1996) Recovery of Hesperodiaptomus arcticus populations from diapausing eggs following elimination by stocked salmonids. Canadian Journal of Zoology $74: 1292-1297$

Pastoriono P, Polazzo F, Bertoli M, Santi M, Righetti M, Pizzul E, Prearo M (2018) Consequences of fish introductions in fishless Alpine lakes: preliminary notes from a sanitary point of view. Turkish Journal of Fisheries and Aquatic Sciences 20 http://doi.org/10.4194/1303-2712-v20_01_01

Power M, Power G, Caron F, Doucett RR, Guiguer KR (2002) Growth and dietary niche in Salvelinus fontinalis as revealed by stable isotope analysis. Environmental Biology of Fishes 64:75-85

Resh VH, Beche LA, McElravy EP (2005) How common are rare taxa in long-term benthic macroinvertebrate surveys? The Journal of the North American Benthological Society 24:976-989

Rolla M, Biffoni G, Brighenti S, Iacobuzio R, Liautaud K, Pasquaretta C, Tiberti R (2018) Predation by introduced fish can magnify the terrestrial arthropod subsidies in mountain lakes. Canadian Journal of Fisheries and Aquatic Sciences 75:1453-1464

RStudio Team (2015) RStudio: Integrated Development for R. RStudio, Inc., Boston, MA URL http://www.rstudio.com/

Sánchez J, Cobo F, González MA (2007) Biología y la alimentación del salvelino, Salvelinus fontinalis (Mitchill, 1814), en cinco lagunas glaciares de la Sierra de Gredos (Ávila, España). Nova Acta Cientifica Compostelana (Bioloxía) 16:129-144

Sarnelle O, Knapp RA (2004) Zooplankton recovery after fish removal: limitations of the egg bank. Limnology and Oceanography 49:1382-1392

Schabetsberger R, Luger MS, Drozdowski G, Jagsch A (2009) Only the small survive: monitoring longterm changes in the zooplankton community of an Alpine lake after fish introduction. Biological Invasions 11:1335-1345

Schilling EG, Lofton CS, Huryn AD (2009) Macroinvertebrates as indicators of fish absence in naturally fishless lakes. Freshwater Biology 54:181-202

Schindler DE, Knapp RA, Leavitt PR (2011) Alteration of nutrient cycles and algal production resulting from fish introductions into mountain lakes. Ecosystems 4:308-321

Schindler DW, Parker BR (2002) Biological pollutants: alien fishes in mountain lakes. Water, Air and Soil Pollution: Focus 2:379-397

Scott WB, Scott MG (1988) Atlantic fishes of Canada. Canadian Bulletin of Fisheries and Aquatic Sciences 219: 731p.

Sienkiewicz E, Gąsiorowski M (2016) The effect of fish stocking on mountain lake plankton communities identified using palaeobiological analyses of bottom sediment cores. Journal of Paleolimnology 55:129-150

Spears BM, Futter MN, Jeppesen E, Huser BJ, Ives S, Davidson TA, Adrian R, Angeler DG, Burthe SJ, Carvalho L, Daunt F, Gsell AS, Hessen DO, Janssen ABG, Mackay EB, May L, Moorhouse H, Olsen S, Søndergaard M, Woods H, Thackeray SJ (2017) Ecological resilience in lakes and the conjunction fallacy. Nature Ecology and Evolution 1:1616-1624

Stenson JAE (1982) Fish impact on rotifer community structure. Hydrobiologia 87:57-64

Stenson JAE (1983) Changes in the relative abundance of Polyarthra vulgaris and P. dolichoptera, following the elimination of fish. Hydrobiologia 104:269-273

Stoch F, Vagaggini D, Margaritora FG (2019) Macroecological and spatial patterns in the distribution of cladocerans in Alpine lakes. Limnetica 38:119-136 
Symons CC, Shurin JB (2016) Climate constrains lake community and ecosystem responses to introduced predators. Proceedings of the Royal Society B: Biological Sciences 283:20160825

Tachet H, Richoux P, Bournaud M, Usseglio-Polatera P (2000) Invertébrés d'eau douce. Systématique, biologie, écologie. CNRS Editions, Paris

Tiberti R (2017) Can satellite ponds buffer the impact of introduced fish on newts in a mountain pond network?. Aquatic Conservation Marine and Freshwater Ecosystems 28:457-465

Tiberti R, Bogliani G, Brighenti S, Iacobuzio R, Liautaud K, Rolla M, von Hardanberg A, Bassano B (2018) Recovery of high mountain Alpine lakes after the eradication of introduced brook trout Salvelinus fontinalis using non-chemical methods. Biological Invasions 21:875-894

Tiberti R, Brighenti S, Canedoli C, Iacobuzio R, Pasquini G, Rolla M (2016) The diet of introduced brook trout (Salvelinus fontinalis; Mitchill, 1814) in an alpine area and a literature review on its feeding ecology. Journal of Limnology 75:488-507

Tiberti R, von Hardenberg A, Bogliani G (2014) Ecological impact of introduced fish in high altitude lakes: a case of study from the European Alps. Hydrobiologia 724:1-19

Tonolli L, Tonolli V (1951) Ossevacioni sulla biologia ed ecologia di 170 popolamenti zooplanctonici di laghi italiani di alta quota. Memorie dell'Istituto Italiano di Idrobiología "Dottore Marco Marchi" 6:53-136

Toro M (2007) Las lagunas del Macizo de Peñalara (Sierra de Guadarrama): de los primeros naturalistas y científicos a los problemas de conservación a comienzos del siglo XXI. Boletín de la Real Sociedad Española de Historia Natural, Sección Biológica 102:127-148

Toro M, Granados I (2001) Las lagunas del Parque Regional de la Sierra de Gredos. Monografías de la Red de Espacios Naturales de Castilla y León, Serie Técnica: Junta de Castilla y León, Valladolid

Toro M, Granados I (2002) Restoration of a Small High Mountain Lake after Recent Tourist Impact: The Importance of Limnological Monitoring and Palaeolimnology. Water, Air and Soil Pollution: Focus 2:295-310

Toro M, Granados I, Robles S, Montes C (2006) High mountain lakes of the Central Range (Iberian Peninsula): Regional limnology and environmental changes. Limnetica 25:217-252

Torres-Esquivias JA, Arenas González RM, Fernández Delgado C (2009) La malvasía cabeciblanca (Oxyura leucocephala) de nuevo en la Laguna de Zóñar. Oxyura: Revista sobre las Zonas Húmedas 12:41-48

Usseglio-Polatera P, Bournaud M, Richoux P, Tachet H (2000) Biological and ecological traits of benthic freshwater macroinvertebrates: relationships and definition of groups with similar traits. Freshwater Biology 43:175-205

Usseglio-Polatera P, Philippe R, Bournaud M, Tachet H (2001) A functional classification of benthic macroinvertebrates based on biological and ecological traits: Application to river condition assessment and stream management. Archiv fuer Hydrobiologie Supplement 139:53-83

Velasco JL, Álvarez M, García Sánchez-Colomer M (2005) Comunidades planctónicas de los lagos de montaña de Neila (Burgos, España). Ecología 19:75-94

Ventura M, Tiberti R, Buchaca T, Buñay D, Sabás I, Miró A (2017) Why should we preserve fishless high mountain lakes?. In: Catalan J, Ninot JM, Añiz M (eds) High Mountain Conservation in a Changing World, Springer-Verlag, Cham, pp 181-205

Vicente-Serrano SM, Rodríguez-Camino E, Domínguez-Castro F, El Kenawy A, Azorín-Molina C (2017) An updated review on recent trends in observational surface atmospheric variables and their extremes over Spain. Geographical Research Letters 43:209-232 
Villéger S, Ramos J, Flores D, Mouillot D (2010) Contrasting changes in taxonomic vs. functional diversity of tropical fish communities after habitat degradation. Ecological Applications 20:1512-1522

Ward JH (1963) Hierarchical groupings to optimize an objective function. Journal of the American Statistical Association 58:236-244

Wattiez C (1981) Biomasse du zooplancton et productivity des cladoceres d'eaux de degre trophique different. Annales de Limnologie 17:219-236

Winder M, Bürgi HR, Spaak P (2003) Mechanisms regulating zooplankton populations in a high-mountain lake. Freshwater Biology 48:795-809

Winder M, Monaghan MT, Spaak P (2001) Have human impacts changed alpine zooplankton diversity over the past 100 years?. Artic, Antarctic and Alpine Research 33:467-475

Wissinger SA, McIntosh AR, Greig HS (2006) Impacts of introduced brown and rainbow trout on benthic invertebrate communities in shallow New Zealand lakes. Freshwater Biology 51:2009-2028

\section{TABLES}

Table 1. Main morphometric and limnological (range of mean values) characteristics of Lake Grande de Peñalara.

Table 2. Number of campaigns and months with sampling performed every year for macroinvertebrates and zooplankton in Lake Grande de Peñalara (a month can have more than one campaign). Brook trout presence is indicated for every year.

Table 3. Selected traits of aquatic macroinvertebrates for the assessment of their response and recovery after fish eradication in Lake Grande de Peñalara.

Table 4. Macroinvertebrate taxa (presence/absence data) identified each year in Lake Grande de Peñalara sorted by the number of years when they have been detected. The number of campaigns per year is shown in Table 2. Absence in a given year should be considered as taxa not found, but absence was not proven.

Table 5. Selected traits and categories (see Table 3 for description of traits) for the taxa found in Lake Grande de Peñalara. Scores are assigned to each taxon according to its affinity for that category, following the fuzzy coding approach by Chevenet et al. (1994) and Tachet (2000).

\section{FIGURES}


Figure 1. Location of Sierra de Guadarrama (a) and Lake Grande de Peñalara (nearby ponds are indicated) (b) in Central Iberian Peninsula, bathymetric map (c) and summer view (d) of the lake.

Figure 2. Number of taxa per year (richness) of macroinvertebrates found in Lake Grande de Peñalara before, during and after the eradication of brook trout. Years without any taxa data were not sampled (see Table 2). Mean value of richness pre- and post- eradication is indicated.

Figure 3. Dendrograms of classification analysis of years (a) and taxa (b) according to matrix of Table 4. Groups (Y prefix for years and $\mathrm{T}$ prefix for taxa) are defined according to criteria of fish presence/absence for years and frequency of appearance and fish presence/absence for taxa. See the text for explanations of the clusters codes.

Figure 4. Distribution of (a) the different modalities of traits (see codes in Table 3) and (b) years on the F1F2 factorial plane as result of the Fuzzy Correspondence Analysis (FCA). Years are classified into 3 groups: I. Before fish eradication; II. Years during eradication; III. After fish eradication.

Figure 5. Distribution of modalities of the taxa traits on the first two axes of the fuzzy correspondence analysis (FCA) (data from matrix traits/years). Each modality in each trait plot is located at the weighted average of the year position (dot) representing that one. Correlation ratios with both axis and ordination plot scale are indicated. These ratios represent proportions of the total variance explained by each axis to quantify the distance among modalities of a variable. Table with values and cumulative proportion of inertia $(100 \%=1)$ for the Fuzzy Correspondence Analysis of relative affinity of sampled years for the different categories of selected traits is shown.

Figure 6. Time course of the zooplankton assemblages during the period 1991-2012 in Lake Grande de Peñalara. For each species, the years when its presence has been detected are shaded in green. Species abundances (in bars) (individuals / m3) are only available for 1997 and the period 20032012. The blue lines link the dates of greatest abundance each year with quantitative data.

Figure 7. Dendrograms of classification analysis of years (a) and taxa (b) according to data from Figure 6. Groups are defined according to criteria of fish presence/absence for years and frequency of appearance and fish presence/absence for taxa.

Figure 8. Biplot of the Redundancy Analysis (RDA) showing the four dominant species in the zooplankton assemblages and year (a) and month (b) as explicative variables. Both variables have been represented in two different panels for clearness.

\section{TABLES}

Table 1.

\begin{tabular}{ll}
\hline Coordinates (Datum ETRS89) & Lat. 40,83993 - Long. -3,95740 \\
Altitude (m) & 2019 \\
Watershed Area (ha) & 44.2 \\
Lake surface Area $\left(\mathrm{m}^{2}\right)$ & 6964 \\
Lake Volume $\left(\mathrm{m}^{3}\right)$ & 11563 \\
Maximum Depth $(\mathrm{m})$ & 4.8 \\
\hline
\end{tabular}




\begin{tabular}{ll}
\hline Mean residence time (days) & 9 \\
Inlets/Outlets & 1 (temporary) / 1 \\
Maximum Summer temperature $\left({ }^{\circ} \mathrm{C}\right)$ & $18-20$ \\
Conductivity $\left(\mu \mathrm{S} / \mathrm{cm} 25^{\circ} \mathrm{C}\right)$ & $6-20$ \\
$\mathrm{pH}$ & $5.9-7.5$ \\
Alkalinity $\left(\mu \mathrm{eq} / 1 \mathrm{HCO}_{3}^{-}\right)$ & $20-100$ \\
$\mathrm{Chl} a(\mu \mathrm{g} / \mathrm{l})$ & $0.6-3.4$ \\
\hline
\end{tabular}

Table 2

\begin{tabular}{|c|c|c|c|c|c|}
\hline \multirow[b]{2}{*}{ Fish presence } & \multirow[b]{2}{*}{ Year } & \multicolumn{2}{|r|}{ Macroinvertebrates } & \multicolumn{2}{|r|}{ Zooplankton } \\
\hline & & $\begin{array}{c}\mathrm{N}^{\mathrm{o}} \\
\text { camp. }\end{array}$ & $\begin{array}{l}\text { Months with } 1 \text { or more } \\
\text { samplings }\end{array}$ & $\begin{array}{c}\mathrm{N}^{\mathrm{o}} \\
\text { camp. }\end{array}$ & $\begin{array}{l}\text { Months with } 1 \text { or more } \\
\text { samplings }\end{array}$ \\
\hline Yes & $\begin{array}{l}1986 \\
1990 \\
1991 \\
1992 \\
1993 \\
1994 \\
1995 \\
1996 \\
1997\end{array}$ & $\begin{array}{l}3 \\
1 \\
0 \\
0 \\
3 \\
0 \\
3 \\
5 \\
8\end{array}$ & $\begin{array}{l}9-11-12 \\
8 \\
- \\
- \\
7-8 \\
- \\
7-8-10 \\
5-6-7-8-10 \\
3-4\end{array}$ & $\begin{array}{c}0 \\
0 \\
2 \\
6 \\
9 \\
2 \\
6 \\
11 \\
4\end{array}$ & $\begin{array}{l}- \\
- \\
1-9 \\
9-10-11-12 \\
1-2-3-4-5-6-7-8-9 \\
- \\
7-8-9-10-11-12 \\
1-2-3-4-5-6-7-8-9-10-11 \\
6-7-8-9\end{array}$ \\
\hline $\begin{array}{l}\text { Eradication } \\
(1999-2002)\end{array}$ & $\begin{array}{l}2001 \\
2002\end{array}$ & $\begin{array}{l}2 \\
5\end{array}$ & $\begin{array}{l}6-7 \\
6-7-8-9-10\end{array}$ & $\begin{array}{l}1 \\
2\end{array}$ & - \\
\hline No & $\begin{array}{l}2003 \\
2004\end{array}$ & $\begin{array}{l}5 \\
6\end{array}$ & $\begin{array}{l}5-7-8-9 \\
4-6-7-8-9-11\end{array}$ & $\begin{array}{l}7 \\
8\end{array}$ & $\begin{array}{l}2-5-7-8-9-11 \\
1-3-4-6-7-8-9-11\end{array}$ \\
\hline
\end{tabular}




\begin{tabular}{l|l|l|l|l|l}
\hline & 2005 & 3 & $6-7$ & 8 & $1-2-3-4-6-7-9$ \\
2006 & 6 & $4-5-7-9-11$ & 8 & $1-3-4-5-7-9-11$ \\
2007 & 5 & $5-6-9-10-11$ & 9 & $2-3-5-6-7-8-9-10-11$ \\
2008 & 4 & $4-6-9$ & 7 & $1-6-7-9-10-12$ \\
2009 & 6 & $5-6-7-9-10-11$ & 6 & $3-5-6-9-10-11$ \\
2010 & 6 & $4-5-6-8-9-11$ & 8 & $1-2-4-5-7-9-11-12$ \\
2011 & 8 & $4-5-6-7-8-9-10-11$ & 9 & $3-4-5-6-7-8-9-10-11$ \\
2012 & 3 & $4-6$ & 9 & $1-2-4-6-7-8-9-10-11$ \\
2013 & 0 & - & 2 & 1 \\
2015 & 1 & 7 & 0 & - \\
2016 & 4 & $6-7-8-9$ & 0 & - \\
2017 & 4 & $6-8-9$ & 0 & - \\
2018 & 4 & $6-7-8-9$ & 0 & - \\
\hline
\end{tabular}

Table 3

\begin{tabular}{|c|c|c|c|c|}
\hline Assemblage & Type & Trait & Modality & Code \\
\hline \multirow{4}{*}{ Macroinvertebrates } & \multirow{4}{*}{ Biology } & $\begin{array}{l}\text { Maximal size }(\mathrm{cm}) \\
\text { (last aquatic stage) }\end{array}$ & $\begin{array}{l}\leq 0.25 \\
>0.25-0.5 \\
>0.5-1 \\
>1-2 \\
>2-4 \\
>4-8\end{array}$ & $\begin{array}{l}\text { a1 } \\
\text { a2 } \\
\text { a3 } \\
\text { a4 } \\
\text { a5 } \\
\text { a6 }\end{array}$ \\
\hline & & Life cycle lenght (year) & $\begin{array}{l}\leq 1 \\
>1\end{array}$ & $\begin{array}{l}\mathrm{b} 1 \\
\mathrm{~b} 2\end{array}$ \\
\hline & & Generations per year & $\begin{array}{l}<1 \\
1 \\
>1\end{array}$ & $\begin{array}{l}\text { c1 } \\
\text { c2 } \\
\text { c3 }\end{array}$ \\
\hline & & Aquatic stages & $\begin{array}{l}\text { Egg } \\
\text { Larva } \\
\text { Pupa } \\
\text { Adult }\end{array}$ & $\begin{array}{l}\mathrm{d} 1 \\
\mathrm{~d} 2 \\
\mathrm{~d} 3 \\
\mathrm{~d} 4\end{array}$ \\
\hline
\end{tabular}




\begin{tabular}{|c|c|c|c|}
\hline \multirow{3}{*}{ Ecology } & Dispersal & $\begin{array}{l}\text { Aquatic passive } \\
\text { Aquatic active } \\
\text { Aerial passive } \\
\text { Aerial active }\end{array}$ & $\begin{array}{l}\mathrm{f} 1 \\
\mathrm{f} 2 \\
\mathrm{f} 3 \\
\mathrm{f} 4\end{array}$ \\
\hline & Microhabitats & $\begin{array}{l}\text { Slabs, boulders, cobbles, pebbles } \\
\text { Gravels } \\
\text { Sand } \\
\text { Silt } \\
\text { Macrophytes, filamentous algae } \\
\text { Microphytes } \\
\text { Twigs, roots } \\
\text { Organic detritus, litter } \\
\text { Mud }\end{array}$ & $\begin{array}{l}\mathrm{t} 1 \\
\mathrm{t} 2 \\
\mathrm{t} 3 \\
\mathrm{t} 4 \\
\mathrm{t} 5 \\
\mathrm{t} 6 \\
\mathrm{t} 7 \\
\mathrm{t} \\
\mathrm{t} \\
\mathrm{t}\end{array}$ \\
\hline & $\begin{array}{l}\text { Locomotion and } \\
\text { substrate relation }\end{array}$ & $\begin{array}{l}\text { Flier } \\
\text { Surface swimmer } \\
\text { Swimmer in open water } \\
\text { Crawler } \\
\text { Burrower (epibenthic) } \\
\text { Interstitial (endobenthic) } \\
\text { Temporarily attached }\end{array}$ & $\begin{array}{l}\text { u1 } \\
\text { u2 } \\
\text { u3 } \\
\text { u4 } \\
\text { u5 } \\
\text { u6 } \\
\text { u7 }\end{array}$ \\
\hline
\end{tabular}

Table 4

\begin{tabular}{|c|c|c|c|c|c|c|c|c|c|c|c|c|c|c|c|c|c|c|c|c|c|c|c|}
\hline \multicolumn{24}{|c|}{ Eradication } \\
\hline Taxa & 1986 & 1990 & 1993 & 1995 & 1996 & 1997 & 2001 & 2002 & 2003 & 2004 & 2005 & 2006 & 2007 & 2008 & 2009 & 2010 & 2011 & 2012 & 2015 & 2016 & 2017 & 2018 & $\begin{array}{c}\mathrm{N}^{\circ} \text { of Years } \\
\text { detected }\end{array}$ \\
\hline Hydrochus & 0 & 0 & 0 & 0 & 0 & 0 & 0 & 0 & 0 & 0 & 0 & 0 & 0 & 0 & 0 & 0 & 0 & 0 & 0 & 0 & 0 & 1 & 1 \\
\hline Hemisphaera & 0 & 0 & 0 & 0 & 0 & 0 & 0 & 0 & 0 & 0 & 0 & 0 & 0 & 0 & 0 & 0 & 0 & 1 & 0 & 0 & 0 & 0 & 1 \\
\hline Helochares & 0 & 0 & 0 & 0 & 0 & 0 & 0 & 0 & 0 & 0 & 0 & 0 & 0 & 0 & 0 & 0 & 1 & 0 & 0 & 0 & 0 & 0 & 1 \\
\hline Amphinemura & 0 & 0 & 0 & 0 & 0 & 0 & 0 & 0 & 0 & 0 & 0 & 0 & 0 & 1 & 0 & 0 & 0 & 0 & 0 & 0 & 0 & 0 & 1 \\
\hline Tipulidae & 0 & 0 & 0 & 0 & 0 & 0 & 0 & 0 & 0 & 0 & 0 & 0 & 0 & 1 & 0 & 0 & 0 & 0 & 0 & 0 & 0 & 0 & 1 \\
\hline Aeshnidae & 0 & 0 & 0 & 0 & 0 & 0 & 0 & 0 & 0 & 0 & 0 & 1 & 0 & 0 & 0 & 0 & 0 & 0 & 0 & 0 & 0 & 0 & 1 \\
\hline Veliidae & 0 & 0 & 0 & 0 & 0 & 0 & 0 & 0 & 0 & 0 & 0 & 0 & 0 & 0 & 0 & 0 & 1 & 0 & 0 & 1 & 0 & 0 & 2 \\
\hline Berosus & 0 & 0 & 0 & 0 & 0 & 0 & 0 & 0 & 0 & 0 & 0 & 0 & 0 & 0 & 0 & 0 & 1 & 1 & 0 & 0 & 0 & 0 & 2 \\
\hline Hydrophilidae & 0 & 0 & 0 & 0 & 0 & 0 & 0 & 0 & 0 & 0 & 0 & 0 & 0 & 1 & 1 & 0 & 0 & 0 & 0 & 0 & 0 & 0 & 2 \\
\hline Acilius & 0 & 0 & 0 & 0 & 0 & 0 & 0 & 0 & 0 & 0 & 0 & 1 & 0 & 0 & 0 & 0 & 0 & 0 & 0 & 0 & 1 & 0 & 2 \\
\hline Hesperocorixa & 0 & 0 & 0 & 0 & 0 & 0 & 0 & 0 & 1 & 0 & 0 & 0 & 0 & 0 & 0 & 0 & 1 & 0 & 0 & 0 & 0 & 0 & 2 \\
\hline Goeridae & 0 & 0 & 0 & 1 & 0 & 0 & 0 & 0 & 1 & 0 & 0 & 0 & 0 & 0 & 0 & 0 & 0 & 0 & 0 & 0 & 0 & 0 & 2 \\
\hline Arctocorixa & 0 & 0 & 0 & 0 & 0 & 0 & 0 & 0 & 0 & 0 & 0 & 0 & 0 & 0 & 0 & 0 & 0 & 1 & 0 & 0 & 1 & 1 & 3 \\
\hline Protonemura & 0 & 0 & 0 & 0 & 0 & 0 & 0 & 0 & 0 & 0 & 0 & 0 & 0 & 1 & 1 & 0 & 0 & 1 & 0 & 0 & 0 & 0 & 3 \\
\hline Psychodidae & 0 & 0 & 0 & 0 & 0 & 0 & 0 & 1 & 1 & 1 & 0 & 0 & 0 & 0 & 0 & 0 & 0 & 0 & 0 & 0 & 0 & 0 & 3 \\
\hline Nemoura & 1 & 0 & 0 & 0 & 0 & 0 & 0 & 0 & 0 & 1 & 0 & 1 & 0 & 0 & 0 & 0 & 0 & 0 & 0 & 0 & 0 & 0 & 3 \\
\hline Gyrinus & 0 & 0 & 0 & 0 & 0 & 0 & 0 & 0 & 0 & 0 & 1 & 0 & 0 & 0 & 0 & 0 & 1 & 0 & 1 & 0 & 0 & 1 & 4 \\
\hline Limoniidae & 0 & 0 & 0 & 0 & 0 & 0 & 1 & 0 & 0 & 0 & 0 & 1 & 0 & 1 & 0 & 0 & 1 & 0 & 0 & 0 & 0 & 0 & 4 \\
\hline Polycelis & 0 & 0 & 0 & 1 & 0 & 0 & 0 & 0 & 1 & 0 & 0 & 0 & 0 & 0 & 0 & 0 & 0 & 1 & 0 & 1 & 0 & 0 & 4 \\
\hline Micronecta & 0 & 0 & 0 & 0 & 0 & 0 & 0 & 0 & 1 & 0 & 0 & 0 & 0 & 0 & 1 & 0 & 0 & 0 & 1 & 1 & 0 & 1 & 5 \\
\hline Corixa & 0 & 0 & 0 & 0 & 0 & 0 & 0 & 1 & 1 & 0 & 0 & 0 & 0 & 1 & 0 & 0 & 1 & 0 & 0 & 1 & 0 & 0 & 5 \\
\hline Ceratopogonidae & 0 & 0 & 0 & 0 & 0 & 0 & 0 & 1 & 0 & 0 & 0 & 0 & 0 & 0 & 1 & 1 & 1 & 1 & 0 & 0 & 0 & 0 & 5 \\
\hline Helobdella & 0 & 0 & 0 & 0 & 0 & 0 & 1 & 1 & 1 & 1 & 0 & 1 & 0 & 0 & 0 & 0 & 0 & 0 & 0 & 0 & 0 & 0 & 5 \\
\hline Plectrocnemia & 0 & 0 & 0 & 1 & 0 & 0 & 0 & 0 & 0 & 1 & 0 & 0 & 0 & 0 & 1 & 0 & 1 & 1 & 0 & 0 & 0 & 0 & 5 \\
\hline Pleidae & 0 & 0 & 0 & 0 & 0 & 0 & 0 & 0 & 0 & 1 & 1 & 1 & 0 & 1 & 0 & 1 & 0 & 1 & 0 & 0 & 0 & 0 & 6 \\
\hline Dytiscus & 0 & 0 & 0 & 0 & 0 & 0 & 0 & 0 & 0 & 1 & 1 & 0 & 0 & 1 & 0 & 1 & 0 & 1 & 0 & 0 & 1 & 0 & 6 \\
\hline Colymbetes & 0 & 0 & 0 & 0 & 0 & 0 & 1 & 1 & 0 & 0 & 0 & 0 & 0 & 0 & 1 & 0 & 1 & 0 & 0 & 1 & 1 & 0 & 6 \\
\hline Leuctridae & 0 & 0 & 0 & 0 & 0 & 0 & 1 & 1 & 1 & 1 & 0 & 0 & 1 & 0 & 1 & 0 & 0 & 0 & 0 & 1 & 1 & 0 & 8 \\
\hline Tabanidae & 0 & 0 & 0 & 0 & 0 & 0 & 1 & 1 & 1 & 1 & 1 & 0 & 1 & 1 & 0 & 0 & 1 & 1 & 0 & 0 & 0 & 0 & 9 \\
\hline Hydroporinae & 0 & 0 & 0 & 0 & 0 & 0 & 1 & 0 & 0 & 1 & 0 & 1 & 1 & 1 & 1 & 1 & 1 & 1 & 1 & 1 & 1 & 0 & 12 \\
\hline Helophorus & 1 & 0 & 0 & 0 & 0 & 0 & 0 & 0 & 0 & 1 & 1 & 1 & 1 & 1 & 1 & 1 & 1 & 1 & 1 & 1 & 1 & 1 & 14 \\
\hline Gerris & 0 & 0 & 0 & 0 & 0 & 0 & 0 & 0 & 1 & 1 & 1 & 1 & 1 & 1 & 1 & 1 & 1 & 1 & 1 & 1 & 1 & 1 & 14 \\
\hline Cloeon & 1 & 0 & 0 & 0 & 0 & 0 & 0 & 0 & 1 & 1 & 1 & 1 & 1 & 1 & 1 & 1 & 1 & 1 & 1 & 1 & 1 & 1 & 15 \\
\hline Sigara & 0 & 0 & 0 & 0 & 0 & 0 & 0 & 1 & 1 & 1 & 1 & 1 & 1 & 1 & 1 & 1 & 1 & 1 & 1 & 1 & 1 & 1 & 15 \\
\hline Agabus & 0 & 0 & 0 & 0 & 0 & 0 & 1 & 1 & 1 & 1 & 0 & 1 & 1 & 1 & 1 & 1 & 1 & 1 & 1 & 1 & 1 & 1 & 15 \\
\hline Notonecta & 0 & 0 & 0 & 0 & 0 & 0 & 1 & 1 & 1 & 1 & 1 & 1 & 1 & 1 & 1 & 1 & 1 & 1 & 1 & 1 & 1 & 1 & 16 \\
\hline Allogamus & 0 & 0 & 0 & 1 & 1 & 1 & 1 & 1 & 1 & 1 & 1 & 1 & 1 & 1 & 1 & 1 & 1 & 1 & 1 & 1 & 1 & 1 & 19 \\
\hline Oulimnius & 0 & 0 & 1 & 1 & 1 & 1 & 1 & 1 & 1 & 1 & 1 & 1 & 1 & 1 & 1 & 1 & 1 & 1 & 1 & 1 & 1 & 1 & 20 \\
\hline Athripsodes & 1 & 1 & 1 & 1 & 1 & 1 & 1 & 1 & 1 & 1 & 1 & 1 & 1 & 1 & 1 & 1 & 1 & 1 & 1 & 1 & 1 & 1 & 22 \\
\hline Chironomidae & 1 & 1 & 1 & 1 & 1 & 1 & 1 & 1 & 1 & 1 & 1 & 1 & 1 & 1 & 1 & 1 & 1 & 1 & 1 & 1 & 1 & 1 & 22 \\
\hline Habrophlebia & 1 & 1 & 1 & 1 & 1 & 1 & 1 & 1 & 1 & 1 & 1 & 1 & 1 & 1 & 1 & 1 & 1 & 1 & 1 & 1 & 1 & 1 & 22 \\
\hline Limnephilinae & 1 & 1 & 1 & 1 & 1 & 1 & 1 & 1 & 1 & 1 & 1 & 1 & 1 & 1 & 1 & 1 & 1 & 1 & 1 & 1 & 1 & 1 & 22 \\
\hline Oligochaeta & 1 & 1 & 1 & 1 & 1 & 1 & 1 & 1 & 1 & 1 & 1 & 1 & 1 & 1 & 1 & 1 & 1 & 1 & 1 & 1 & 1 & 1 & 22 \\
\hline Sialis & 1 & 1 & 1 & 1 & 1 & 1 & 1 & 1 & 1 & 1 & 1 & 1 & 1 & 1 & 1 & 1 & 1 & 1 & 1 & 1 & 1 & 1 & 22 \\
\hline Pisidium & 1 & 1 & 1 & 1 & 1 & 1 & 1 & 1 & 1 & 1 & 1 & 1 & 1 & 1 & 1 & 1 & 1 & 1 & 1 & 1 & 1 & 1 & 22 \\
\hline
\end{tabular}


Table 5

\begin{tabular}{|c|c|c|c|c|c|c|c|c|c|c|c|c|c|c|c|c|c|c|c|c|c|c|c|c|c|c|c|c|c|c|c|c|c|c|c|}
\hline Taxa & a1 & a2 & a3 & a4 & a5 & a6 & b1 & b2 & c1 & c2 & c3 & d1 & d2 & d3 & d4 & f1 & $\mathrm{f} 2$ & f3 & f4 & $\mathrm{t} 1$ & t2 & $\mathrm{t} 3$ & t4 & t5 & t6 & t7 & t8 & t9 & u1 & u2 & u3 & u4 & u5 & u6 & u7 \\
\hline Acilius & 0 & 0 & 0 & 3 & 0 & 0 & 0 & 3 & 0 & 3 & 0 & 3 & 3 & 0 & 2 & 0 & 1 & 0 & 3 & 0 & 0 & 0 & 0 & 3 & 0 & 0 & 3 & 3 & 1 & 0 & 3 & 3 & 0 & 0 & 0 \\
\hline Aeshnidae & 0 & 0 & 0 & 0 & 2 & 3 & 1 & 3 & 3 & 1 & 0 & 1 & 3 & 0 & 0 & 1 & 1 & 0 & 3 & 0 & 0 & 0 & 0 & 4 & 0 & 2 & 3 & 2 & 0 & 0 & 0 & 5 & 0 & & 0 \\
\hline Agabus & 0 & 0 & 3 & 2 & 0 & 0 & 0 & 3 & 0 & 3 & 1 & 3 & 3 & 0 & 2 & 1 & 1 & 0 & 3 & 0 & 1 & 1 & 1 & 3 & 0 & 0 & 3 & 3 & 1 & 0 & 3 & 3 & 0 & & 0 \\
\hline Allogamus & 0 & 0 & 0 & 1 & 3 & 0 & 3 & 0 & 0 & 3 & 0 & 3 & 3 & 3 & 0 & & & & 3 & 3 & 2 & 0 & 0 & 0 & 0 & 0 & 3 & 1 & 0 & 0 & 0 & 5 & 0 & 0 & 0 \\
\hline Amphinemura & 0 & 1 & 3 & 0 & 0 & 0 & 3 & 0 & 0 & 0 & 0 & 3 & 3 & 0 & 0 & 2 & 2 & 0 & 1 & 3 & 0 & 0 & 0 & 4 & 0 & 0 & 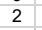 & 0 & 0 & 0 & 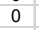 & 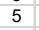 & 0 & 0 & 0 \\
\hline Arctocorixa & 0 & 0 & 3 & 0 & 0 & 0 & 3 & 0 & 0 & 3 & 0 & 3 & 3 & 0 & 2 & 0 & 2 & 0 & 2 & 0 & 0 & 0 & 2 & 2 & 0 & 2 & 0 & 0 & 1 & 0 & 5 & 0 & 0 & 0 & 0 \\
\hline Athripsodes & 0 & 0 & 2 & 2 & 0 & 0 & 3 & 0 & 0 & 3 & 0 & 3 & 3 & 3 & 0 & 2 & 1 & 1 & 3 & 4 & 2 & 1 & 1 & 2 & 0 & 3 & 1 & 1 & 0 & 0 & 0 & 5 & 0 & 0 & 0 \\
\hline Berosus & 0 & 2 & 2 & 0 & 0 & 0 & 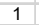 & 3 & 0 & 2 & & 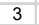 & 3 & 0 & & 0 & 1 & 0 & 3 & 0 & 0 & 0 & 0 & 3 & 3 & 0 & 3 & 3 & 1 & 0 & 3 & 3 & 0 & 0 & 0 \\
\hline Cera & 0 & 0 & 1 & 3 & 0 & 0 & 0 & 0 & 0 & 2 & 2 & 1 & 2 & 2 & 0 & 3 & 1 & 0 & 2 & 2 & 3 & 4 & 1 & 3 & 3 & 3 & 1 & 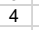 & 1 & 0 & s & 1 & 0 & & 0 \\
\hline Chironomida & 1 & 3 & 2 & 1 & 0 & 0 & 3 & 0 & 0 & 3 & 3 & 0 & 3 & 3 & 0 & 2 & 1 & 3 & 1 & 3 & 1 & 3 & 2 & 4 & 0 & 1 & 1 & 2 & 0 & 0 & 1 & 3 & 1 & 1 & 2 \\
\hline Cloeon & 0 & 0 & 3 & 0 & 0 & 0 & 3 & 0 & 0 & 1 & 3 & 3 & 3 & 0 & 0 & 1 & 2 & 1 & 2 & 1 & 0 & 1 & 1 & 5 & 0 & 0 & 2 & 1 & 0 & 0 & 3 & 1 & 0 & 0 & 0 \\
\hline Colymbetes & 0 & 0 & 0 & 3 & 0 & 0 & 0 & 0 & 0 & 3 & 0 & 3 & 3 & 0 & 2 & 0 & 1 & 0 & 3 & 0 & 0 & 0 & 0 & 3 & 0 & 0 & 3 & 3 & 1 & 0 & 3 & 3 & 0 & 0 & 0 \\
\hline Cor & 0 & 0 & 2 & 3 & 0 & 0 & 3 & 0 & 0 & 3 & 2 & 3 & 3 & 0 & 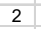 & 0 & 3 & 1 & 3 & 0 & 0 & 0 & 0 & . & 0 & & 2 & 0 & 1 & 0 & 5 & 0 & 0 & & 0 \\
\hline Dytiscu & 0 & 0 & 0 & 0 & 3 & 1 & 0 & 3 & 0 & 3 & 0 & 3 & 3 & 0 & 2 & 0 & 1 & 0 & 3 & 0 & 0 & 0 & 0 & 3 & 0 & 0 & 3 & 3 & 1 & 0 & 3 & 3 & 0 & 0 & 0 \\
\hline Gerris & 0 & 0 & 1 & 3 & 0 & 0 & 2 & 3 & 0 & 2 & 3 & 1 & 2 & 0 & 2 & 1 & 2 & 0 & 3 & 0 & 0 & 0 & 0 & 5 & 0 & 0 & 0 & 0 & 3 & 4 & 0 & 0 & 0 & 0 & 0 \\
\hline Goe & 0 & 0 & 3 & 1 & 0 & 0 & - & 0 & 0 & 0 & 0 & 3 & 3 & 3 & 0 & 1 & 1 & 1 & 2 & 3 & 2 & 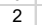 & 0 & 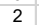 & 0 & . & 0 & 0 & 0 & 0 & 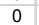 & 5 & 0 & 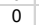 & 0 \\
\hline & 0 & 2 & 3 & 0 & 0 & 0 & 1 & & 0 & 3 & & 3 & & & & 0 & & & & & & & & & & & & 1 & 1 & 3 & 3 & 3 & 0 & & 0 \\
\hline Habrophlebia & 0 & 0 & 3 & 0 & 0 & 0 & 3 & 0 & 0 & 3 & 0 & 3 & 3 & 0 & 0 & 1 & 1 & 1 & 1 & 0 & 0 & 1 & 1 & 2 & 0 & 2 & 3 & 1 & 0 & 0 & 1 & 3 & 0 & 0 & 0 \\
\hline Helobc & 0 & 0 & 3 & 1 & 0 & 0 & 3 & 1 & 0 & 3 & 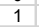 & 3 & 3 & 0 & 3 & 1 & 1 & 0 & 0 & 2 & 0 & 0 & 0 & 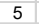 & 0 & 0 & 3 & 0 & 0 & 0 & 0 & 4 & 1 & 0 & 1 \\
\hline & 0 & 2 & 3 & 0 & 0 & 0 & 1 & 3 & 0 & 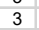 & 1 & 3 & 3 & 0 & & 0 & 1 & & 3 & 0 & 0 & 0 & 0 & 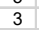 & 0 & 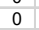 & 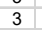 & 0 & 1 & 0 & 3 & 4 & & & 0 \\
\hline & 0 & 3 & 3 & 0 & 0 & 0 & 1 & 3 & 0 & & 1 & & & & & & & & & & & & & & & & & & & & & & & & \\
\hline Hemisphaera & 0 & 3 & 0 & 0 & 0 & 0 & 1 & 0 & 0 & 3 & 1 & 3 & 3 & 0 & 2 & 0 & 1 & 0 & 3 & 0 & 0 & 0 & 0 & 3 & 3 & 0 & 3 & 3 & 1 & 0 & 3 & 0 & 0 & 0 & 0 \\
\hline Hesperocor & 0 & 0 & 3 & 0 & 0 & . & 3 & 0 & 0 & 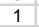 & 1 & 3 & 3 & 0 & 2 & 0 & 2 & 0 & 2 & 0 & 0 & 0 & 0 & 3 & 0 & 0 & 2 & 2 & 1 & 0 & 5 & 0 & 0 & & 0 \\
\hline & 0 & 3 & 0 & 0 & 0 & 0 & 1 & 3 & 0 & 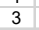 & 1 & 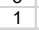 & 0 & 0 & 2 & c & 1 & & 3 & & & & 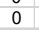 & 5 & 3 & & 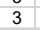 & 3 & 1 & 0 & 3 & 3 & 0 & & 0 \\
\hline & . & 2 & 2 & 0 & 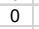 & 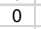 & 1 & 3 & 0 & 3 & 1 & 3 & & & & & & & & & & & & & & & & & 1 & & & & & & 0 \\
\hline Hydrop & 0 & 3 & 1 & 0 & 0 & 0 & 1 & 3 & 0 & 1 & 0 & 3 & 0 & 0 & 2 & 0 & 1 & & 3 & 0 & 1 & 1 & 1 & 3 & 0 & 0 & 3 & 3 & 1 & 0 & 3 & 0 & 0 & 0 & 0 \\
\hline & 0 & 0 & 3 & 1 & 0 & 0 & 3 & 1 & 1 & 3 & 0 & 3 & 3 & 0 & 0 & 2 & 2 & & 1 & 4 & 3 & 2 & 2 & 4 & 0 & 4 & 2 & 0 & 0 & 0 & 0 & 5 & 2 & & 0 \\
\hline & 0 & 0 & 0 & 3 & 0 & 0 & 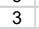 & 0 & 0 & & & & & & & & & & & & & & & & & & & & & & & & & & 0 \\
\hline & 0 & 0 & 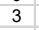 & 1 & 0 & 0 & 1 & 0 & 0 & & & & & & & & & & & & & & & & & & & & & & & & & & 0 \\
\hline Micronecta & 3 & 1 & 0 & 0 & 0 & 0 & 3 & 0 & 0 & 0 & 2 & 0 & 0 & 0 & 0 & 3 & 1 & 0 & 0 & 4 & & 2 & 1 & 4 & 0 & 0 & 2 & 3 & 0 & 0 & 3 & & 0 & 0 & 0 \\
\hline & 0 & 1 & 3 & 0 & . & 0 & 2 & 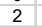 & 2 & 2 & 0 & 3 & & & & & & & 2 & & & & & & & 1 & 3 & 0 & 0 & & & & & & 0 \\
\hline & 0 & 0 & 0 & 3 & 0 & 0 & 3 & 2 & 0 & 3 & 0 & 3 & 3 & 0 & 2 & & & & & & 0 & 0 & 0 & 2 & 0 & 0 & 1 & 1 & 2 & 2 & 4 & 0 & & & 0 \\
\hline & 0 & 4 & 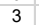 & 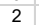 & 1 & 3 & 0 & 1 & 0 & 0 & 3 & 3 & & & & & & & & & & & & & & & & & & & & & & & 0 \\
\hline Oulimn & 0 & 3 & 0 & 0 & 0 & 0 & 1 & 3 & 0 & 3 & u & 3 & 3 & 0 & & 2 & 1 & & & & & & & & & & & 0 & 1 & 0 & 0 & 4 & 0 & & 0 \\
\hline & 0 & 3 & 2 & 1 & 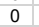 & 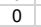 & 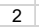 & & & & & & & & & & & & & & & 4 & 4 & & & 1 & 3 & 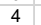 & & & & & 4 & & 2 \\
\hline & 0 & 0 & 0 & 3 & 2 & 0 & 2 & 1 & & & & & & & & & & & & & & & & & & & & & & & & & & & 3 \\
\hline Pleid & 1 & 3 & 0 & 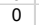 & 0 & 0 & 3 & 0 & 0 & 3 & 0 & 3 & 3 & 0 & 2 & & & & & & & & & 4 & & c & C & 1 & c & 0 & 5 & & & & 0 \\
\hline & 1 & 0 & 1 & 3 & 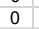 & 0 & 0 & 3 & 0 & 3 & 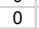 & 3 & 3 & & & 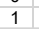 & & ( & 0 & & 0 & 0 & 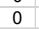 & 3 & 0 & 3 & 2 & 0 & & 1 & & & 0 & & 0 \\
\hline & 0 & 0 & 3 & 1 & 0 & 0 & 3 & 0 & & & & & & & & & & & 1 & 4 & & 1 & 0 & 4 & 0 & 1 & 2 & 0 & 0 & 0 & 0 & 5 & 0 & 0 & 0 \\
\hline Psyc & 0 & 0 & 3 & 0 & 0 & 0 & 3 & 0 & 0 & 1 & 3 & & & 2 & & & & & & & & 2 & & 5 & 0 & 3 & 4 & 3 & 0 & 0 & 0 & 2 & 0 & & 0 \\
\hline Siz & 0 & 0 & 0 & 3 & 2 & 0 & 0 & 3 & 3 & 1 & 0 & & & & & & & & & & & & & & & & & & & & & & & & 0 \\
\hline & 0 & 1 & 3 & 0 & 0 & 0 & 3 & 2 & 0 & 2 & 2 & 3 & 3 & 0 & 2 & 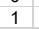 & 2 & 1 & 2 & 0 & 1 & 2 & 1 & 3 & 0 & 0 & 0 & 0 & 1 & 0 & & 0 & 0 & 0 & 0 \\
\hline Tabs & 0 & 0 & 0 & 0 & 3 & 1 & 3 & 0 & 0 & 3 & 0 & 1 & 2 & 0 & 0 & 0 & 1 & 0 & 3 & 0 & 1 & 3 & 0 & 3 & 0 & 0 & 4 & 4 & 0 & 1 & 0 & 2 & 5 & 0 & 0 \\
\hline Tip & 0 & 0 & 0 & 0 & 3 & 2 & 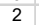 & 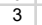 & 1 & 5 & 1 & 2 & 2 & 5 & . & 0 & & 0 & 1 & 2 & 2 & 1 & 1 & 4 & 0 & 2 & 4 & 0 & 0 & 0 & 0 & 1 & 4 & 0 & 0 \\
\hline Vel & 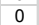 & 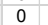 & & 0 & & 0 & & & & & & & & & & & & & & & & & & & & & & & & & & & & & 0 \\
\hline
\end{tabular}




\section{FIGURES}

Figure 1.
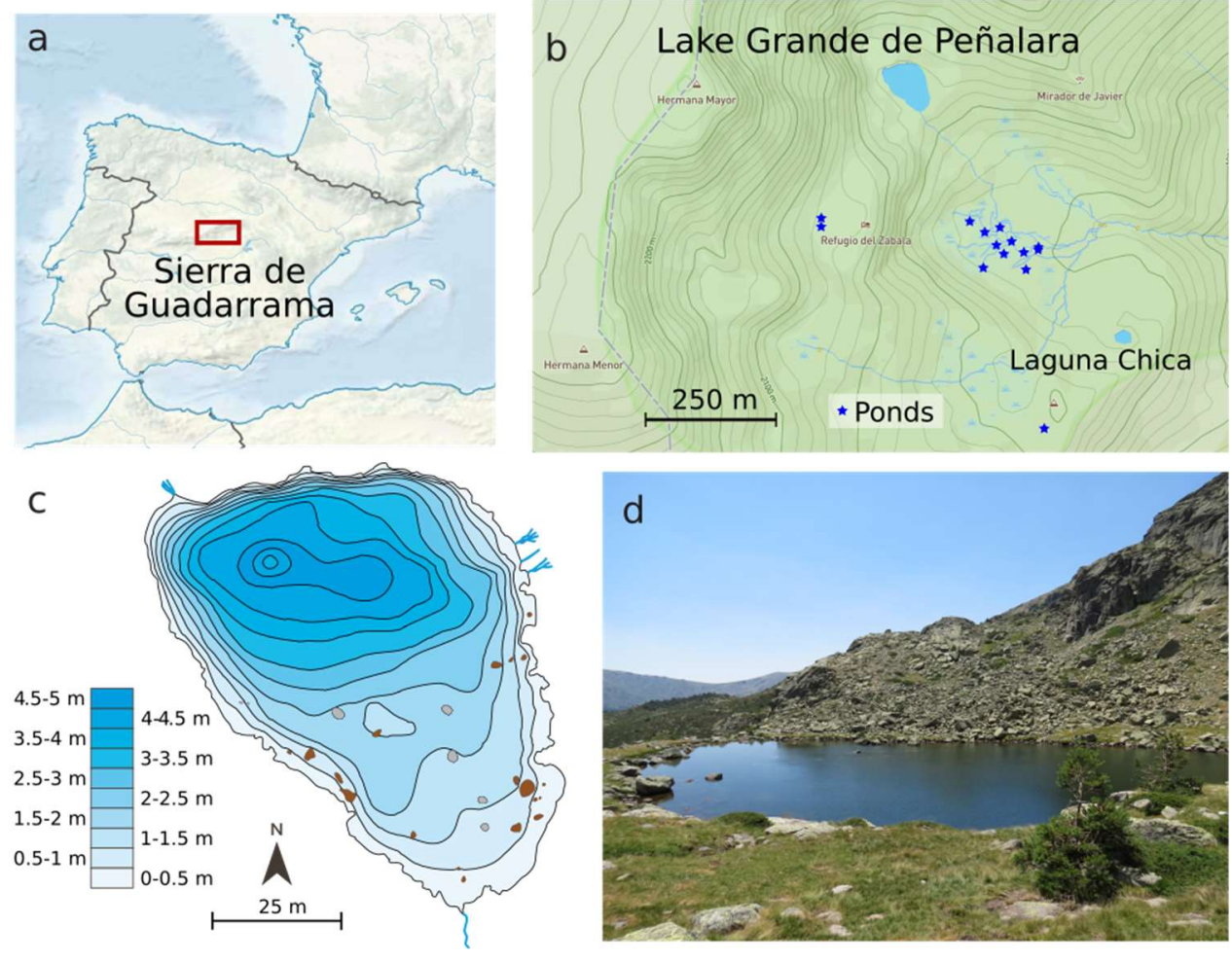

Figure 2. 


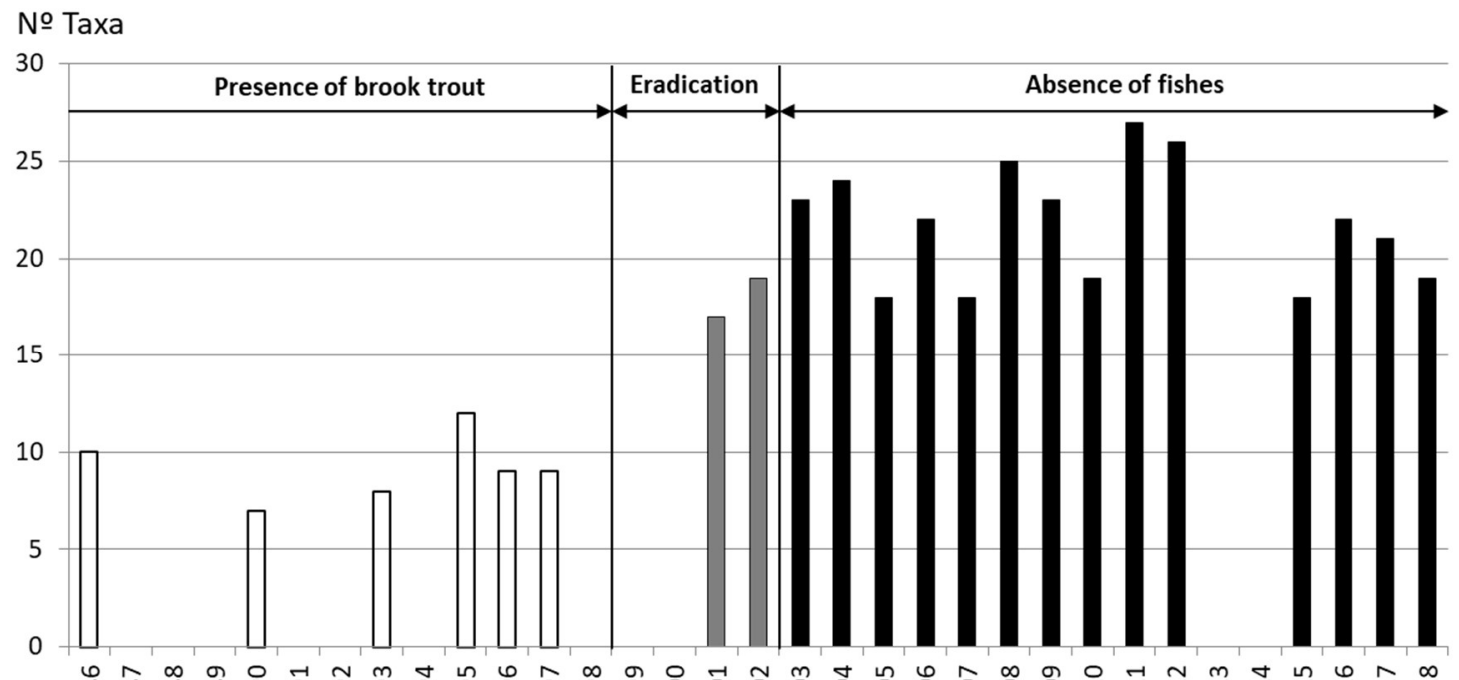

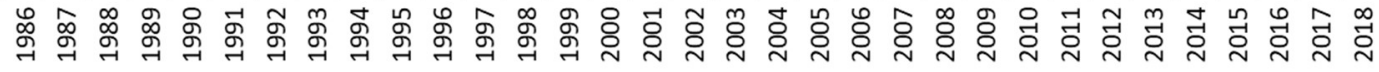

Figure 3.
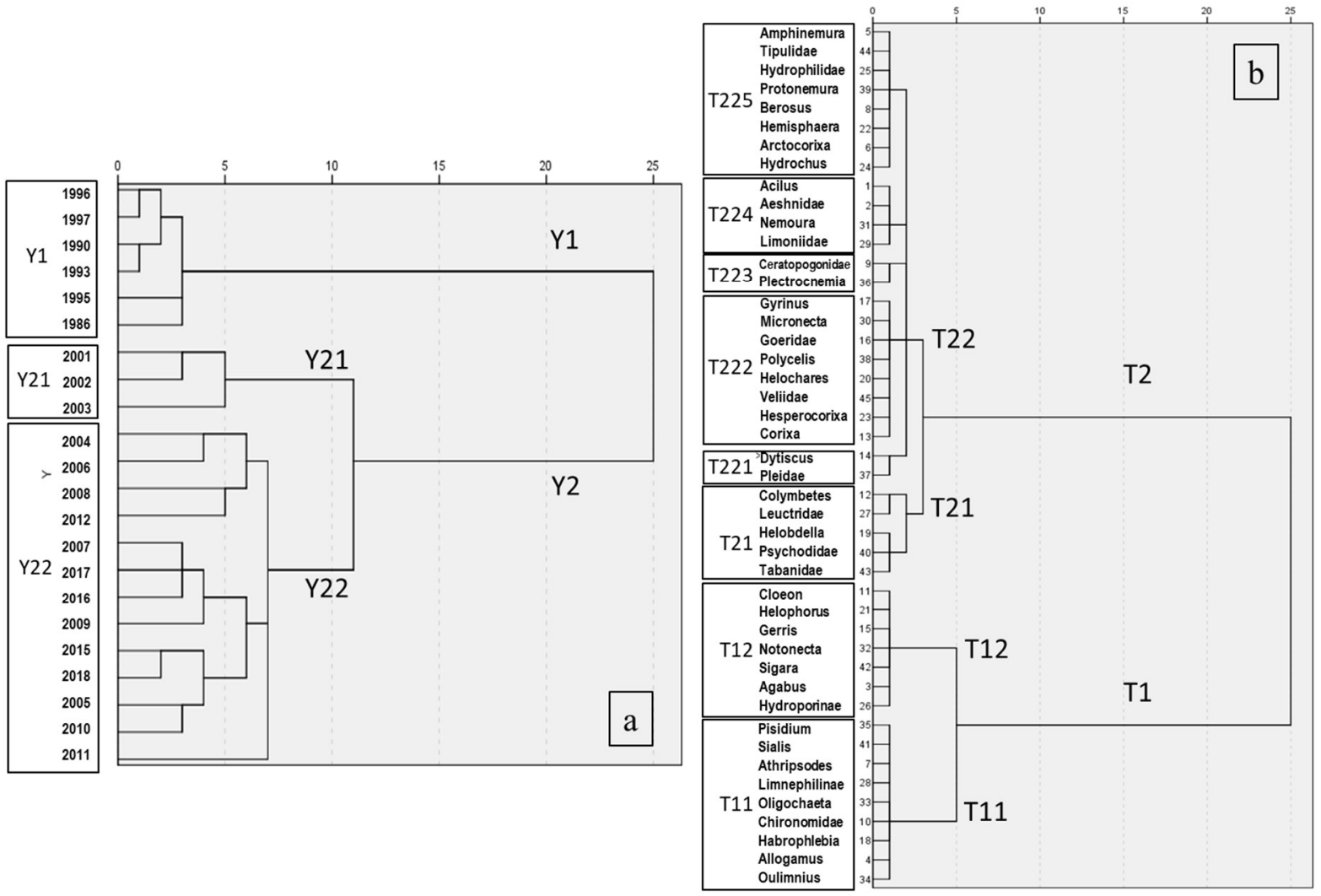
Figure 4. 

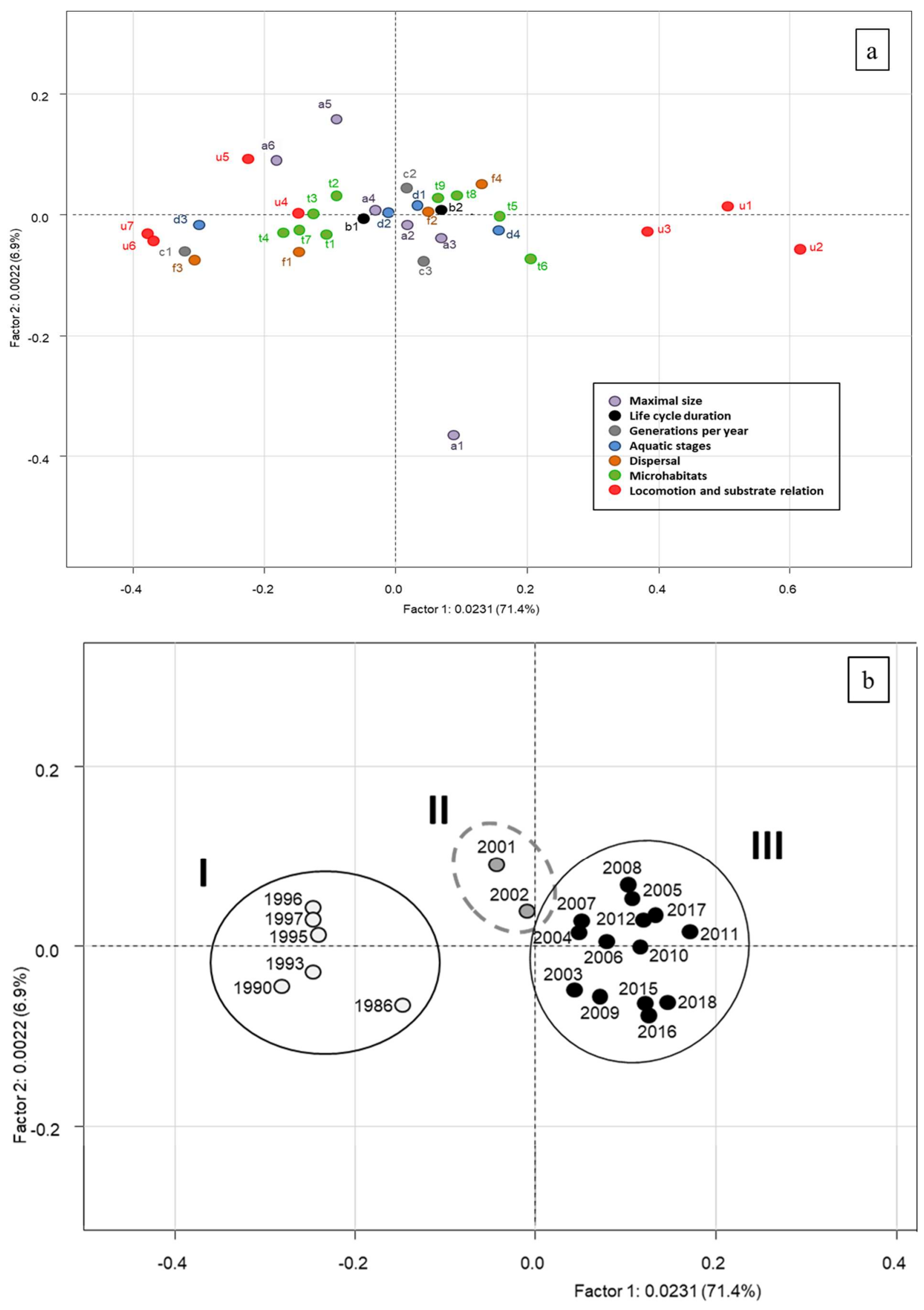
Figure 5.

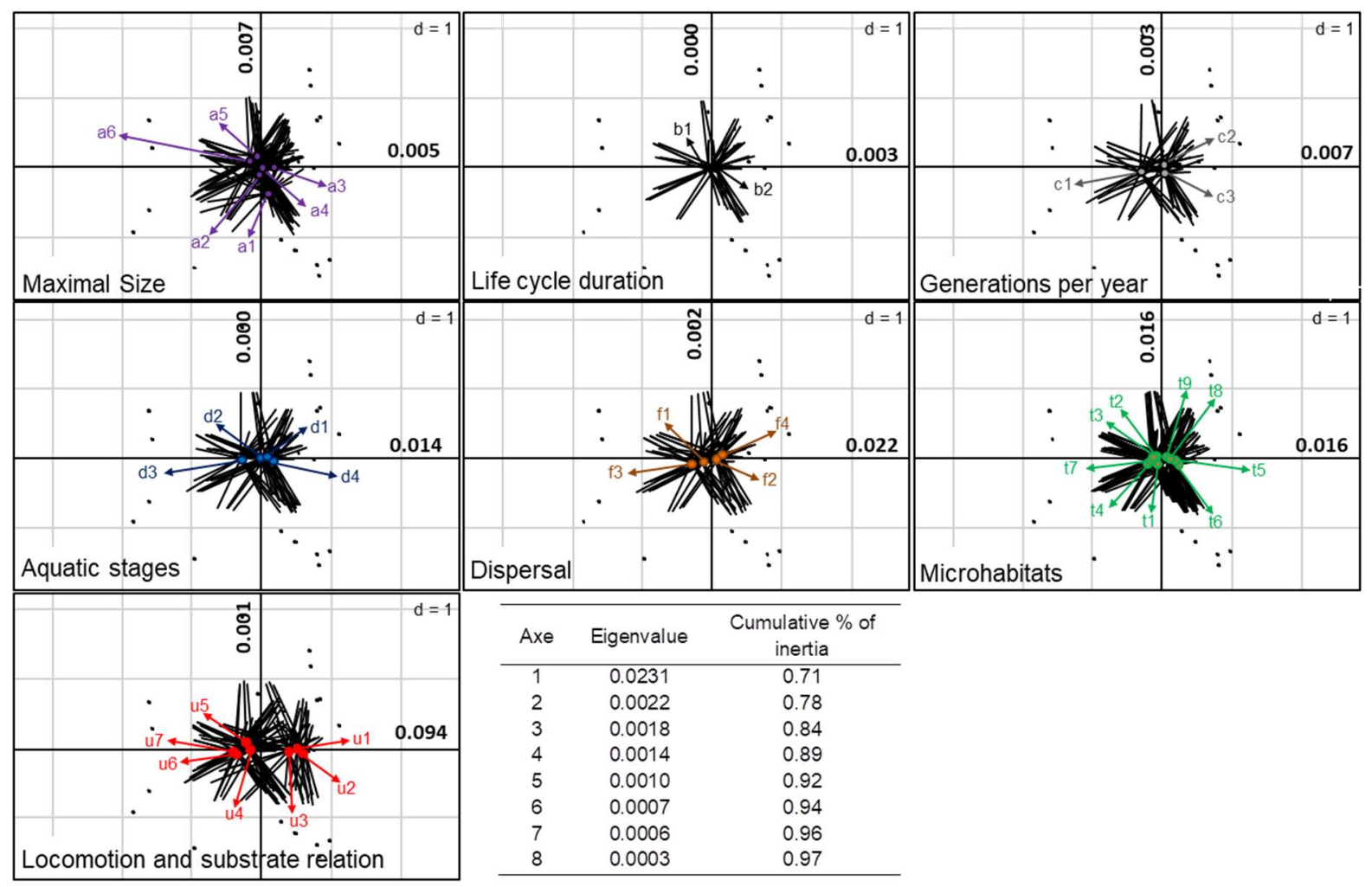

Figure 6. 


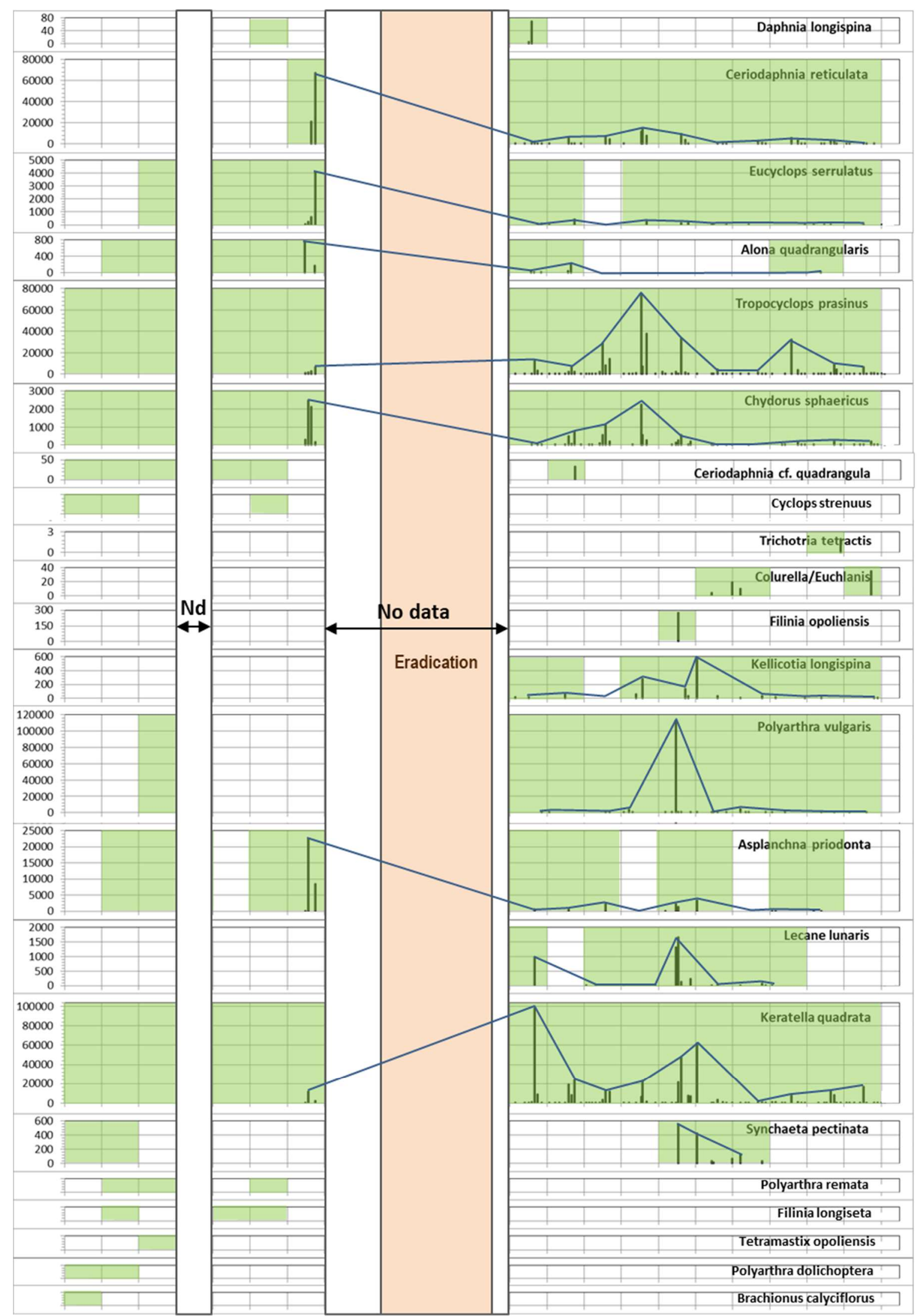

1991199219931994199519961997199819992000200120022003200420052006200720082009201020112012 
Figure 7.
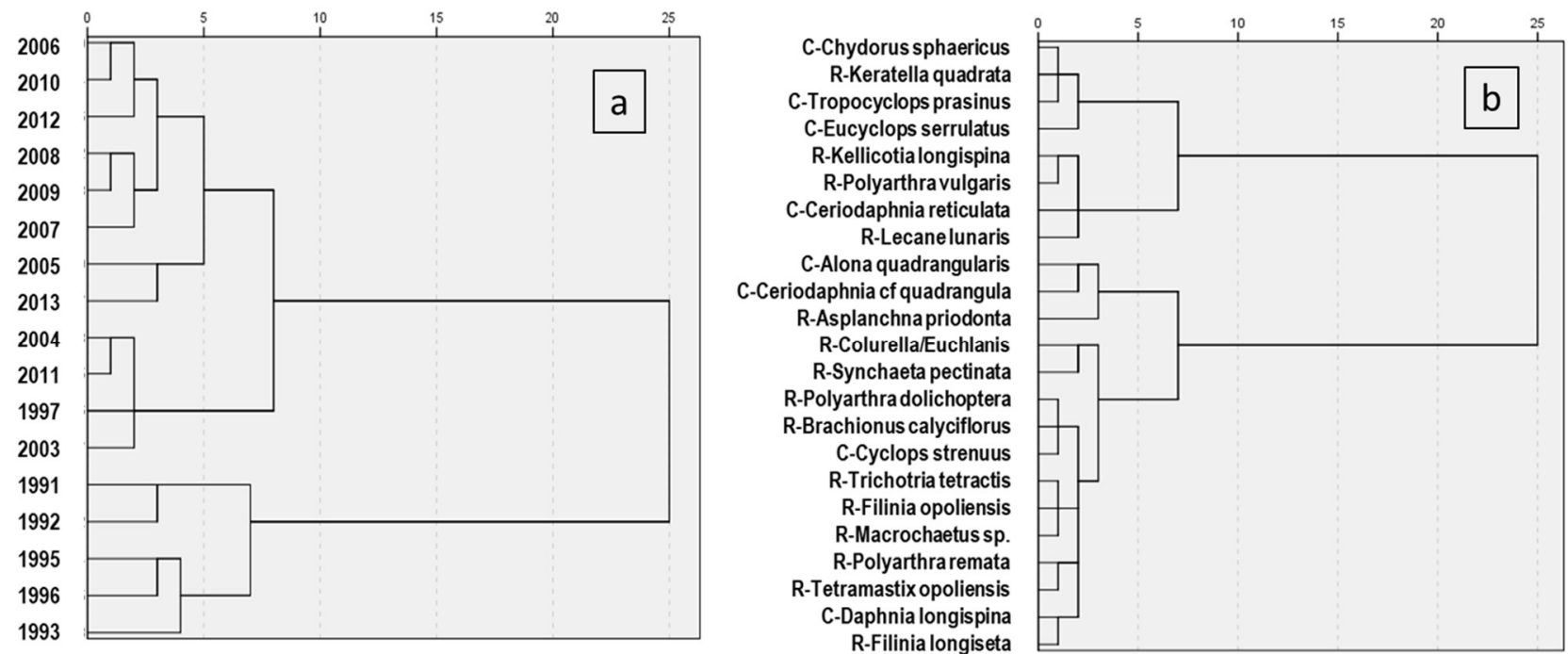

Figure 8.

a

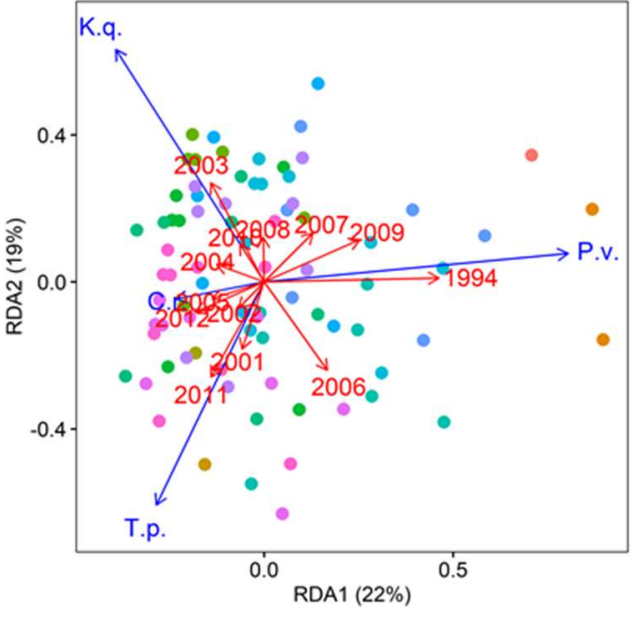

b

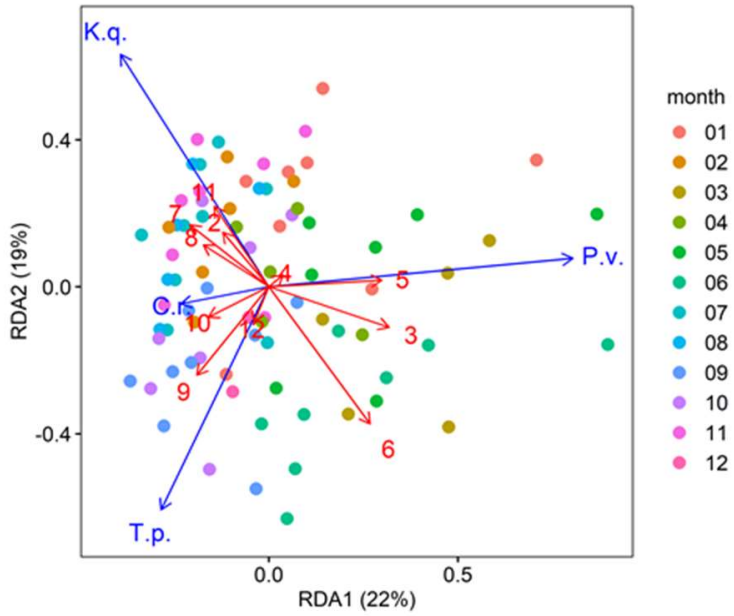

